\title{
Chitosan And N, N, N-Trimethyl Chitosan
}

\section{Nanoparticle Encapsulation Of Ocimum Gratissimum Essential Oil: Optimised Synthesis, In Vitro Release And Bioactivity}

\author{
This article was published in the following Dove Press journal: \\ International Journal of Nanomedicine
}

\section{Confidence Onyebuchi (D) Doğa Kavaz $\mathbb{D}^{1,2}$}

'Bioengineering Department, Faculty of Engineering, Cyprus International University, Haspolat- Lefkoșa 98258, Northern Cyprus via Mersin 10 Turkey; ${ }^{2}$ Biotechnology Research Centre, Cyprus International University, HaspolatLefkoșa 99258, Northern Cyprus via Mersin 10 Turkey
Correspondence: Doğa Kavaz Bioengineering Department, Faculty of Engineering, Cyprus International University, Haspolat- Lefkoșa 98258, Northern Cyprus via Mersin 10 Turkey Email dkavaz@ciu.edu.tr
Background: The encapsulation of plant essential oils (EOs) with polymeric materials (e.g. chitosan (CS) and N, N, N-trimethyl chitosan (TMC)) and the further reduction of the polymers into their nano sizes are gaining research interest in nanotechnology due to potential applications in medical drug delivery systems as well as the food and pharmaceutical industry. The present study reports a novel approach for the synthesis of Ocimum gratissimum essential oil (OGEO)-loaded CS and TMC nanoparticles with distinct bioactive and physiochemical properties.

Methods: The OGEO-loaded CS and TMC nanoparticles were characterised using various microscopic and spectroscopic techniques. The bioactive compounds in Ocimum gratissimum methanolic extract (OG-MeOH) and EOs was evinced with gas chromatography-mass spectrometry (GC-MS). Total phenolic content (TPC) of OGEO and OG-MeOH was determined using the Folin-Ciocalteu method. The in vitro drug release kinetic pattern was ascertained by membrane dialysis, while antioxidant activity was determined by the 2,2-diphenyl-1picrylhydrozyl (DPPH) free radical scavenging method. The disc diffusion method was used for antibacterial activity evaluation, while MTT and a trypan blue dye exclusion assay were used to assess cytotoxic activity on MDA-MB-231 breast cancer cells.

Results: GC-MS analysis revealed components that have not been previously reported for Ocimum gratissimum. The maximum OGEO cumulative drug release percentage in vitro was observed at pH 3 for both OGEO-loaded chitosan nanoparticles (OGEO-CSNPs) and OGEOloaded N, N, N-trimethyl chitosan nanoparticles (OGEO-TMCNPs). The antioxidant activity of OGEO-CSNPs and OGEO-TMCNPs never reached a steady state after $75 \mathrm{~h}$. OGEOTMCNPs exhibited antibacterial activity at a lower concentration for both Gram-negative and Gram-positive food pathogens. In vitro cytotoxicity revealed the increased toxicity of OGEO-TMCNPs on MDA-MB-231 breast cancer cell lines.

Conclusion: OGEO-loaded CS and TMC nanoparticles were synthesised using a novel material optimisation approach. The synthesised nanoparticles have shown a promising application in the pharmaceutical and food industries.

Keywords: chitosan derivatives, nanoparticles, Ocimum gratissimum essential oils, in vitro release kinetics, foodborne pathogens, antioxidant capacity, cytotoxicity

\section{Introduction}

Foodborne illness resulting from food contamination by pathogenic bacteria such as Bacillus cereus (B. cereus), ${ }^{1}$ Staphylococcus aureus (S. aureus), ${ }^{2}$ Salmonella typhimurium (S. typhimurium) ${ }^{3}$ and Escherichia coli $(E . \text { coli })^{4}$ is considered a global 
health concern. ${ }^{5}$ Cancer involves abnormal cell division, which is also a global problem that poses a great threat to human health. ${ }^{6}$ Recent statistics has shown that mortality due to breast cancer accounts for $30 \%$ of all recent cancers among women in $2018 .^{7}$ Moreover, evidence has demonstrated the link between oxidative stress and cancer development. ${ }^{8}$ One of the challenges in cancer treatment is finding a method of diagnosis and treatment that is effective and target specific. ${ }^{8}$ This represents a major drawback in the diagnosis and treatment of cancer and other diseases and has led to the development of nanomedicine an area of nanotechnology involving the manipulation of matter within the nanoscale range of $1-100 \mathrm{~nm}$ at $10^{-9}$ dimension. ${ }^{9}$ The medical applications of nanotechnology involve the use of both chemical and physical methods for the synthesis of organic and inorganic nanoparticles that are biocompatible for transporting drugs with high target specificity. ${ }^{8}$ Nanoparticles are capable of improving drug permeation across cell membranes ${ }^{10}$ and controlling the release of the encapsulated drug. ${ }^{9}$ Chitosan is currently being explored due to its unique properties as a nanocarrier for the delivery of antimicrobial, anticancer and antioxidative agents of natural origin, such as plant essential oils (EOs).$^{8-11}$ Ocimum gratissimum (OG) is a herbaceous plant belonging to the Lamiaceae family. This plant is indigenous to tropical, savanna and coastal areas. OG flowers and leaves have been used in the traditional treatment of bacterial infections, fevers and colds, as well as in the preparation of infusions due to its EO richness. ${ }^{12}$ EOs are hydrophobic liquids that are volatile in nature and have a distinct odour. They are composed of several bioactive components, such as phenols, terpenes, flavonols, sterols, terpenoids, and several aromatic compounds. ${ }^{5}$ However, notwithstanding the increased applicability of plant EOs in diverse food, medical and pharmaceutical sectors, their lipophilic nature, unstable mixes, sensitivity to diverse environmental condition (oxygen, pressure, chemicals, light, and heat) and short effect overtime constrain their use in food and medical applications. ${ }^{11-13}$ Hence, it is currently believed that the nano-encapsulation of EOs using polymeric substances such chitosan will surmount the above challenges. Nanoencapsulation does not only protect the EOs' bioactive components from degradation due to contact with unfavourable environmental conditions but also leads to the synthesis of novel materials with distinct material properties at the nanoscale. ${ }^{14}$

Chitosan (CS) is a linear cationic polysaccharide that is obtained by the partial deacetylation of chitin, the second most abundant polysaccharide. ${ }^{15-17}$ Structurally, CS consists of $\beta$-(1-4) $N$-acetyl-d-glucosamine and $\beta-(1,4)-2-$ amino-2-deoxy-D-glucopyranose units. ${ }^{18}$ Previous studies have demonstrated the applications of CS in the field of medicine and pharmaceutical research due to their mucoadhesive properties as well as their antibacterial, anticancer and permeation-enhancing ability for targeted drug and protein delivery. ${ }^{17,19}$ Notably, a composite of CS with other polymeric material has proven useful in regenerative medicine ${ }^{20}$ However, one drawback in the applicability of CS is the poor solubility at neutral and alkaline conditions, which decreases drug delivery efficiency at $\mathrm{pH}$ values above $6 .{ }^{21}$ This led to the synthesis of N, N, Ntrimethyl chitosan (TMC), a quaternised derivative of CS that is soluble at different $\mathrm{pH}$ and has improved biological and physiological properties including immunostimulatory ability, high stability, non-toxicity, high charge density and biodegradability. ${ }^{15-19}$ TMC has shown a potential use as an adjuvant and in gene delivery due to its ability to form polyplexes with DNA. ${ }^{17,22}$

The aim of this study is to propose a novel approach for the optimised synthesis of Ocimum gratissimum essential oil (OGEO)-loaded nanoparticles with distinct physiochemical properties. Also, to the best of our knowledge, the bioactivities and in vitro release kinetic pattern of OGEO-encapsulated CS and TMC nanoparticles at varying physiological $\mathrm{pH}$ conditions ( $\mathrm{pH} 3$ and $\mathrm{pH}$ 7.4) have not been elucidated in the literature to date. In this context, OGEO encapsulation in CS and TMC nanostructures, its subsequent in vitro release kinetic pattern and their bioactivities as anticancer, antibacterial and antioxidant agents form the primary basis of this study.

\section{Materials And Methods \\ Materials}

Chitosan (90\% deacetylation, 150,000 Da), potassium iodide, sodium chloride, sodium triphosphate pentabasic (TPP), 1,1-diphenyl-2-picrylhydrazyl (DPPH), MuellerHinton agar (MHA), Mueller-Hinton Broth (MHB), Folin-Ciocalteu reagent, sodium carbonate, ciprofloxacin, tween 80 and chloramphenicol were purchased from Sigma-Aldrich, USA. Iodomethane, sodium hydroxide, $\mathrm{N}$-methyl-2-pyrrolidone, acetone, acetic acid, ethanol, hydrochloric acid, methanol, Dulbecco's modified eagle's medium (DMEM) and phosphate-buffered saline (PBS) were purchased from Merck, Germany. 


\section{Extraction Of O. Gratissimum EOs And Methanolic Extract}

The extraction of $O$. gratissimum EOs and the methanolic extract was performed as defined by Grbic-Ljaljevic et al and Pavithra et al, respectively, with little modification. ${ }^{23,24}$ For EO extraction, $100 \mathrm{~g}$ of the pulverised leaves were subjected to hydrodistillation with $\mathrm{H}_{2} \mathrm{O}(800 \mathrm{~mL})$ for $4 \mathrm{~h}$ in a Clevenger apparatus. Anhydrous sodium sulphate was used to remove excess water from the crude EO. For the methanolic extract, lipid degradation using the Soxhlet method using pure methanol $(250 \mathrm{~mL})$ was adopted. The extracts were recovered using a rotary evaporator (Heidolph 3600127, Heidolph ${ }^{\mathrm{TM}}$ Germany). The crude extract was lyophilised with a freeze dryer and stored in a desiccator at $4{ }^{\circ} \mathrm{C}$ until use.

\section{GC-MS Analysis Of O. Gratissimum Essential Oils And Methanolic Extract} The GC-MS (GCMS-QP2010 SE, Shimadzu, Japan) was used to analyse the biochemical constituents of the $O$. gratissimum EOs and methanolic extracts as prescribed by Gasparetto et al, with few modifications. ${ }^{3}$ The qualitative analysis was performed with a fused silica capillary column (HP-5Ms, $30 \times 0.25,0.25 \mu \mathrm{m}$, film thickness) using helium (flow-rate, 1 $\left.\mathrm{mL} \mathrm{min}^{-1}\right)$. The oven temperature was set at $40{ }^{\circ} \mathrm{C}$ and held for 5 mins, then increased to reach $270{ }^{\circ} \mathrm{C}$ at a rate of $3{ }^{\circ} \mathrm{C} / \mathrm{min}$ with a split ratio of $60: 1$. A temperature of $180^{\circ} \mathrm{C}$ was set for the ion sources and connection parts, and the MS was operated using an interface temperature of $240{ }^{\circ} \mathrm{C}$. Electron impact (EI) mode and $70 \mathrm{eV}$ ionisation energy were used. The delay time for MS prior to scanning was 5 mins. Samples were run fully at a range of 50 to $650 \mathrm{~m} / \mathrm{z}$. OGEO and OG-MeOH component identification were performed by comparing retention indices and matching the recorded mass spectra of each compound with the Willey MS libraries and NIST 14 mass spectral library of chemicals.

\section{Total Phenolic Content Determination}

The Folin-Ciocalteu method as described by Shahidi and Zhong was adopted in the determination of total phenolic content (TPC) of OGEO and OG-MeOH, with slight modification. ${ }^{25}$ Briefly, $500 \mu \mathrm{L}$ of Folin-Ciocalteu reagent $(1 \% \mathrm{v} / \mathrm{v})$ was added to $100 \mu \mathrm{L}$ of the OGEO and OG-MeOH $\left(0.5 \mathrm{mg} \mathrm{mL}^{-1}\right)$ and then gently mixed and allowed to stand for $5 \mathrm{~min}$. Then, $400 \mu \mathrm{L}$ of $\mathrm{Na}_{2} \mathrm{CO}_{3}(20 \% \mathrm{w} / \mathrm{w})$ was added to the mixture followed by incubation in dark conditions at $25^{\circ} \mathrm{C}$. A UV-visible spectrophotometer (UV-2450, Shimadzu, Japan) was used to measure the absorbance of the samples at 765 $\mathrm{nm}$ against a distilled water blank. Gallic acid standards were used for the calibration curve. The linear regression of the garlic acid standard curve was used to determine the TPC of the samples, with results being expressed as milligrams of garlic acid equivalent per gram dry weight of plant extracts (mg GAE/g). Experiments were repeated at least three times $(n \geq 3)$.

\section{Preparation Of Chitosan And N, N, N- Trimethyl Chitosan Nanoparticles} Synthesis Of N, N, N-Trimethyl Chitosan Polymer

The initial step for TMC polymer synthesis involves the methylation of $\mathrm{CS}$, while the subsequent phase involves TMC nanoparticle synthesis with the obtained TMC polymer. A diagrammatic representation describing the procedural steps of TMC polymer synthesis is shown in Figure 1. Briefly, 5.75 $\mathrm{mL}$ of iodomethane, $40 \mathrm{~mL}$ of 1-methylpyrrolidin-2-one, $1 \mathrm{~g}$ of CS, and $2.4 \mathrm{~g}$ of potassium iodide were mixed with $5.5 \mathrm{~mL}$ sodium hydroxide (15\%) until a clear solution was formed. The solution was heated at $60{ }^{\circ} \mathrm{C}$ for $6 \mathrm{~h}$ using a Liebig condenser. Upon cooling to room temperature, acetone was used to isolate the product after centrifugation. The exchange of $\mathrm{I}^{-}$with $\mathrm{Cl}^{-}$was achieved by dissolving the product in $\mathrm{NaCl}$ $(5.0 \%, \mathrm{w} / \mathrm{w})$ solution. The product was recovered with acetone and dried to obtain a white powder.

Optimised Loading Of OGEO Into Chitosan And N, N, N-Trimethyl Chitosan Nanoparticles

Optimisation techniques involving different percentage concentrations of TMC, CS, OGEO, TPP, rotation per minute (rpm) and stirring time (min) were adopted in other to select the best method to create the optimal particle size, as determined by the Zetasizer (Zetasizer Nano ZS, Malvern Panalytical, UK). A graphical illustration for the optimised synthesis of OGEO-loaded chitosan and $\mathrm{N}, \mathrm{N}, \mathrm{N}$-trimethyl chitosan nanoparticle is presented in Figure 2. Briefly, TMC and CS solutions of $0.25 \%, 0.5 \%$ and $1 \%(\mathrm{w} / \mathrm{v})$ were suspended in $\mathrm{H}_{2} \mathrm{O}(\mathrm{pH} 5.2)$ and acetic acid $(1 \% \mathrm{v} / \mathrm{v})$, respectively, and stirred for $24 \mathrm{~h}$. The CS and TMC suspension was filtered with a Millipore filter $(0.65 \mu \mathrm{m})$. OGEO $(0.25,0.5$ and $1 \mathrm{~g})$ was then slowly added to the CS and TMC solution $(40 \mathrm{~mL})$ and maintained at a $\mathrm{pH}$ of 4.5. Homogenisation of the solution was performed at different revolution per minute (rpm) rates $(5000,10,000$ and 15,000). Furthermore, different concentrations of TPP $(0.1 \%, 0.4 \%, 0.7 \%, 1 \%$ and $1.5 \%(\mathrm{w} / \mathrm{v})$ 

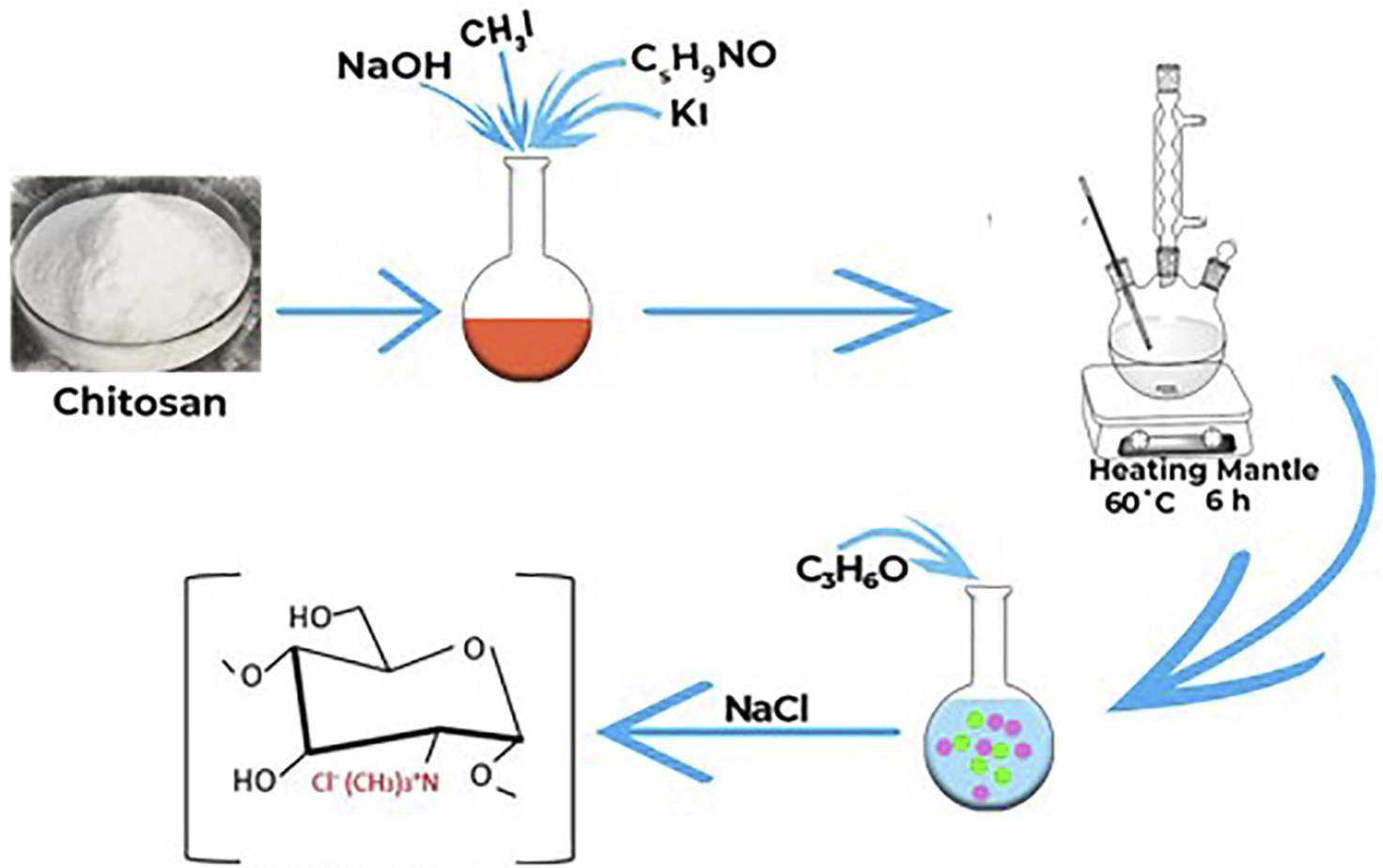

$N, N, N \cdot$ trimethyl chitosan

Figure I Schematic illustration of chitosan methylation for the synthesis of trimethyl chitosan polymer.

Abbreviations: $\mathrm{NaOH}$, sodium hydroxide; $\mathrm{CH}_{3}$ l, Methyl iodide; $\mathrm{C}_{5} \mathrm{H}_{9} \mathrm{NO}, \mathrm{N}$-Methyl-2-pyrrolidone; $\mathrm{KI}$, Potassium iodide; $\mathrm{C}_{3} \mathrm{H}_{6} \mathrm{O}$, acetone; $\mathrm{NaCl}$, Sodium chloride.

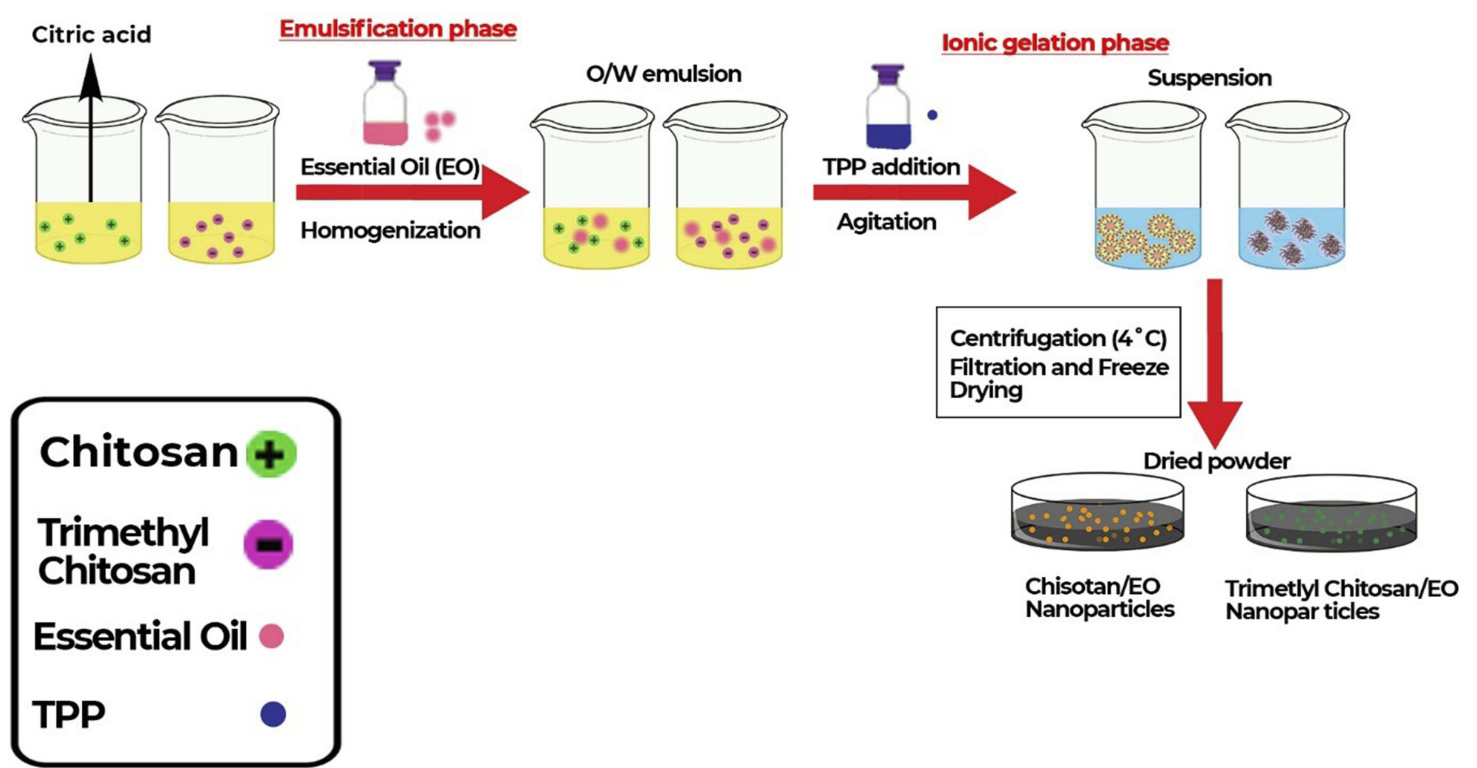

Figure 2 Process illustration for the optimised synthesis of Ocimum gratissimum essential oil-loaded chitosan and $N, N, N$ chitosan nanoparticles. Abbreviation: TTP, tripolyphosphate.

were added to the mixtures, which served as the crosslinker. The mixture was further stirred for different revolution times $(15,30,45$ and $60 \mathrm{~min})$. Nanoparticles were then collected by centrifuging at $4{ }^{\circ} \mathrm{C}$ for $30 \mathrm{~min}$ at 6000 $\mathrm{rpm}$. The synthesised nanoparticles were stored at $4{ }^{\circ} \mathrm{C}$ prior to further analysis. 


\section{Characterisation Of Synthesised \\ Nanoparticles}

Molecular Characterisation By Fourier-Transform

Infrared Spectroscopy (FT-IR)

OGEO, TMCNP, CSNP, OGEO-CSNP and OGEO-

TMCNP FTIR spectra were analysed at a wavelength range of $4000-400 \mathrm{~cm}^{-1}$ with an FTIR spectrophotometer (IR Prestige-21, Shimadzu, Japan).

\section{Morphological Characterisation Of Synthesised Nanoparticles}

The particle morphology of both encapsulated and non-encapsulated EOs was examined using scanning electron microscopy (SEM) (JSM-6610LV, JEOL, Japan). The samples (TMCNPs, CSNPs, OGEO-TMCNPs and OGEO-CSNPs) were made to settle on aluminium stubs with two-fold adhesive tape and were vacuum covered with a thin gold coating prior to examination under $500 \mathrm{x}$ magnification at a voltage acceleration of $20 \mathrm{Kv}$.

Nanoparticle Diameter, Zeta Potential, And Polydispersity Index (PDI)

The particle size and zeta potential of the resultant nanoparticles synthesised using different optimisation techniques were measured using a size and zeta potential analyser (Zetasizer Nano ZS, Malvern Panalytical, UK). The measurements were taken at least three times $(n \geq 3)$ and the average values were recorded.

\section{Determination Of Nanoparticle Loading Capacity (LC) And Encapsulation Efficiency (EE)}

The nanoparticle loading capacity and encapsulation efficiency were determined as follows, $100 \mathrm{mg}$ of CSNPs and TMCNPs loaded with OGEO was added to $\mathrm{HCl}$ solution $(4 \mathrm{~mL}, 1 \mathrm{M})$ and placed in a boiling water bath for $30 \mathrm{~min}$ to dissolve nanoparticles, followed by the addition of $2 \mathrm{~mL}$ of $100 \%$ ethanol into the mixture and centrifugation for 5 min at $9000 \mathrm{rpm}$ and $25^{\circ} \mathrm{C} .{ }^{26}$ The amount of OGEO in the supernatant was $250-400 \mathrm{~nm}$, as measured by a UV-visible spectrophotometer (UV-2450, Shimadzu, Japan). The maximum recorded absorption was $285 \mathrm{~nm}$.

Free OGEO (5-50 $\left.\mathrm{mg} \mathrm{mL}^{-1}\right)$ calibration curves were used to determine the amount of OGEO release. Equations 1 and 2 were used to calculate the LC and EE, respectively. ${ }^{27}$

$$
\% \mathrm{LL}=\frac{\text { Amount of loaded OGEOs }(\mathrm{mg})}{\text { Sample weight }(\mathrm{mg})} \times 100
$$

$$
\% \mathrm{EE}=\frac{\text { Amount of loaded OGEOs }(\mathrm{mg})}{\text { OGEO Initial weight }(\mathrm{mg})} \times 100
$$

\section{In Vitro Studies}

\section{Kinetic Modelling For The In Vitro Release Of $O$. Gratissimum EOs}

The in vitro drug release kinetics of OGEO from CSNPs and TMCNPs were ascertained by membrane dialysis, as proposed by Shetta et al, with few modifications. ${ }^{5}$ Separately, $2 \mathrm{mg}$ of the nanoparticles were suspended in $5 \mathrm{~mL}$ PBS (0.1 M, 1\% Tween-80) of solutions with different physiological $\mathrm{pH}$ values (3.0 and 7.4). Physiological $\mathrm{pH}$ values of 3.0 and 7.4 were selected due to the $\mathrm{pH}$ considerations of the gastrointestinal tract and the $\mathrm{pH}$ of the cancer cells tested. The suspension was placed in a shaking water bath (GFL-1083, thermolab, India) maintained at $37^{\circ} \mathrm{C} \pm 0.5$ and stirred at $100 \mathrm{rpm}$. Samples were withdrawn at predetermined time intervals $(5,10,15,30$, 45, $60 \mathrm{~min}$, and subsequently every $1 \mathrm{~h}$ until $24 \mathrm{~h}$ ). The volume of the withdrawn sample was replaced with PBS solution to maintain a constant volume. Absorbance values of the release OGEO were analysed by a UV-visible spectrophotometer (UV-2450, Shimadzu, Japan) at $270 \mathrm{~nm}$ (maximum absorbance wavelength for OGEO in PBS medium). By using the calibration curve, the OGEO concentration in the withdrawn medium was determined. The calibration curve $(n \geq 3)$ consisted of OGEO concentrations prepared with dissolution media ranging from 0.00025 to $0.08 \mathrm{mg} \mathrm{mL}^{-1}$. Different kinetic models (namely the zero-order model, first-order model, Higuchi model, and Korsmeyer-Peppas kinetic model Equations (3)-(6), respectively) were adapted in order to ascertain the EO rate-controlling processes and release mechanism in vitro. All release experiments were conducted in triplicate (at minimum; $\mathrm{n} \geq 3$ ).

$$
\begin{gathered}
F=K_{0} t \\
\ln (1-\mathrm{F})=-K_{1} t \\
\frac{M_{t}}{M_{\infty}}=K_{k p} t^{n} \\
F=K_{h} t^{1 / 2}
\end{gathered}
$$

Where $\mathrm{F}$ is the amount of $\mathrm{EO}$ released at time $\mathrm{t}$; and $\mathrm{K}_{0}$, $\mathrm{K}_{1}, \mathrm{~K}_{\mathrm{h}}$ and $\mathrm{K}_{\mathrm{kp}}$ are the zero-order, first-order, Higuchi and Korsmeyer-Peppas release rate constants, respectively. 
Subsequently, the most suitable EO release mechanism among the kinetic models was obtained.

\section{Antioxidant Activity Assay}

The 2, 2-diphenyl-1-picrylhydrazyl (DPPH) scavenging properties of the nanoparticles and OGEO and OG-MeOH extract were examined according to the method proposed by Rakmai et al, with few modifications. ${ }^{28}$ Briefly, $2 \mathrm{~mL}$ of ethanolic solution of DPPH $\left(180 \mu \mathrm{mol} \mathrm{L}^{-1}\right)$ was added to OGEO $\left(0.1 \mathrm{mg} \mathrm{mL}^{-1}\right)$, OG-MeOH $\left(0.1 \mathrm{mg} \mathrm{mL}^{-1}\right)$, while $0.2 \mathrm{mg} \mathrm{mL}{ }^{-1}$ was added for the respective nanoparticles. The solutions were kept in the dark at room temperature. The absorbance of the sample was measured at $517 \mathrm{~nm}$ at varying time intervals by a UV-visible spectrophotometer (UV-2450, Shimadzu, Japan). Each test was run in triplicate (at minimum; $n \geq 3$ ). The percentage of DPPH scavenging activity was established using the following equation:

$$
\% \text { DPPH scavenging }=\left[1 \frac{(\text { A sample }- \text { A blank })}{\text { Acontrol }} \times 100\right]
$$

Where:

$$
\begin{aligned}
& \text { A sample }=\text { sample }+ \text { DPPH } \\
& \text { A blank }=\text { sample only } \\
& \text { A control = absorbance of DPPH }
\end{aligned}
$$

\section{Antibacterial Activity}

Suspensions of two strains of Gram-positive bacteria (Staphylococcus aureus (ATCC25923), Bacillus cereus (ATCCI4579)) and Gram-negative bacteria (Escherichia coli (ATCC8739), Salmonella typhimurium (ATCC 13311)) were adjusted to the McFarland standard $\left(1.5 \times 10^{8} \mathrm{CFU} \mathrm{mL}^{-1}\right)$ and spread in an MHA using sterile cotton swabs. Subsequently, the prepared membrane disc was impregnated with the samples (OGEO, OG-MeOH, CSNPs, TMCNPs, OGEO-CSNPs and OGEO-TMCNPs) at respective maximum bactericidal drug concentration (MBC) values of 150, 150, 200, 100, 60 and $40\left(\mathrm{mg} \mathrm{mL}^{-1}\right)$ and placed on the microbial culture plates. For the positive control, chloramphenicol and ampicillin were used. All plates were incubated at $37^{\circ} \mathrm{C}$ for $24 \mathrm{~h}$. Inhibition zones were measured (in $\mathrm{mm}$ ) to determine the antibacterial activity of the samples. ${ }^{29}$ Experiments were conducted at least three times $(\mathrm{n} \geq 3)$.

\section{Proliferation And Cytotoxicity Assay}

The cytotoxicity of OGEO, MeOH, CSNP, TMCNP, OGEOCSNP and OGEO-TMCNP samples on MDA-MB-231 cells was evaluated by trypan blue dye exclusion assays. The use of cell lines was approved by Biotechnology Research Centre
Ethical Committee (BRCEC2011-01). Briefly, cells were plated in $35 \mathrm{~mm}$ dishes $\left(3 \times 10^{4} \mathrm{~mL}^{-1}\right.$ density $)$ and incubated for $24 \mathrm{~h}$ prior to treatment with the different concentration $\left(0-100 \mu \mathrm{g} \mathrm{mL}^{-1}\right)$ of OGEO, OG-MeOH, free nanoparticles and OGEO-loaded nanoparticles. After treatment, cells were incubated for $48 \mathrm{~h}$. Then, $1 \mathrm{~mL}$ DMEM was used for the control group. Meanwhile, $4 \%$ trypan blue dye was added into the cell culture dishes after the 48-h treatment and incubated for $10 \mathrm{~min}$. The culture plates were viewed from 30 randomly selected sites using an inverted microscope (Leica DFC295, Leica microsystem, Germany) to determine the cell viability count (\%). Then, 3-[4, 5-dimethylthiazol-2-yl]-2,5-diphenyltetrazolium bromide (MTT) assays were also adapted to determine the antiproliferation activity of OGEO, OG-MeOH, and the nanoparticles. Briefly, cells were seeded into 96 -well plates at approximately $10^{4}$ cells per well and grown for $24 \mathrm{~h}$. Thereafter, different doses $\left(0-100 \mu \mathrm{g} \mathrm{mL}^{-1}\right)$ of OGEO, OG$\mathrm{MeOH}$, free nanoparticles and OGEO-loaded nanoparticles were added. Supernatants were discarded after the 24-h incubation period. Then, $10 \mu \mathrm{L}$ MTT $\left(5 \mathrm{mg} \mathrm{mL}^{-1}\right)$ was added and incubated for $4 \mathrm{~h}$ at $37{ }^{\circ} \mathrm{C}$. Formazan crystals were then dissolved with $100 \mu \mathrm{L}$ of DMSO. The absorbance was read with a multimode microplate reader at $570 \mathrm{~nm}$. All experiments were performed in triplicate (at minimum) and repeated for three experiments $(n=3)$. The percentage of cell viability was calculated using the following equation:

$$
\% \text { Cell viability }=\left[\frac{(\text { A treated }- \text { A blank })}{(\text { A untreated }- \text { A blank })} \times 100\right]
$$

\section{Statistical Evaluation}

All experiments were repeated multiple times $(n \geq 3)$ and statistical comparisons were expressed using one-way analysis of variance (ANOVA) followed by a Student's two-tailed $t$-test, where necessary. Mean difference was considered nonsignificant at $P>0.05$, significant at $P \leq 0.05$ and very significant at $P \leq 0.0001$. Statistical computation and analyses were performed using the SPSS program (SPSS version 23, SPSS Inc.). Graphical representations of results were created with OriginPro (version 2016).

\section{Results And Discussion Chemical Composition Analysis Of O. Gratissimum EOs And Methanolic Extract}

The percentage chemical composition of $O$. gratissimum essential oils (EOs) and methanolic extracts were obtained from the GC-MS as peak area vs. retention time (Figure 3A 

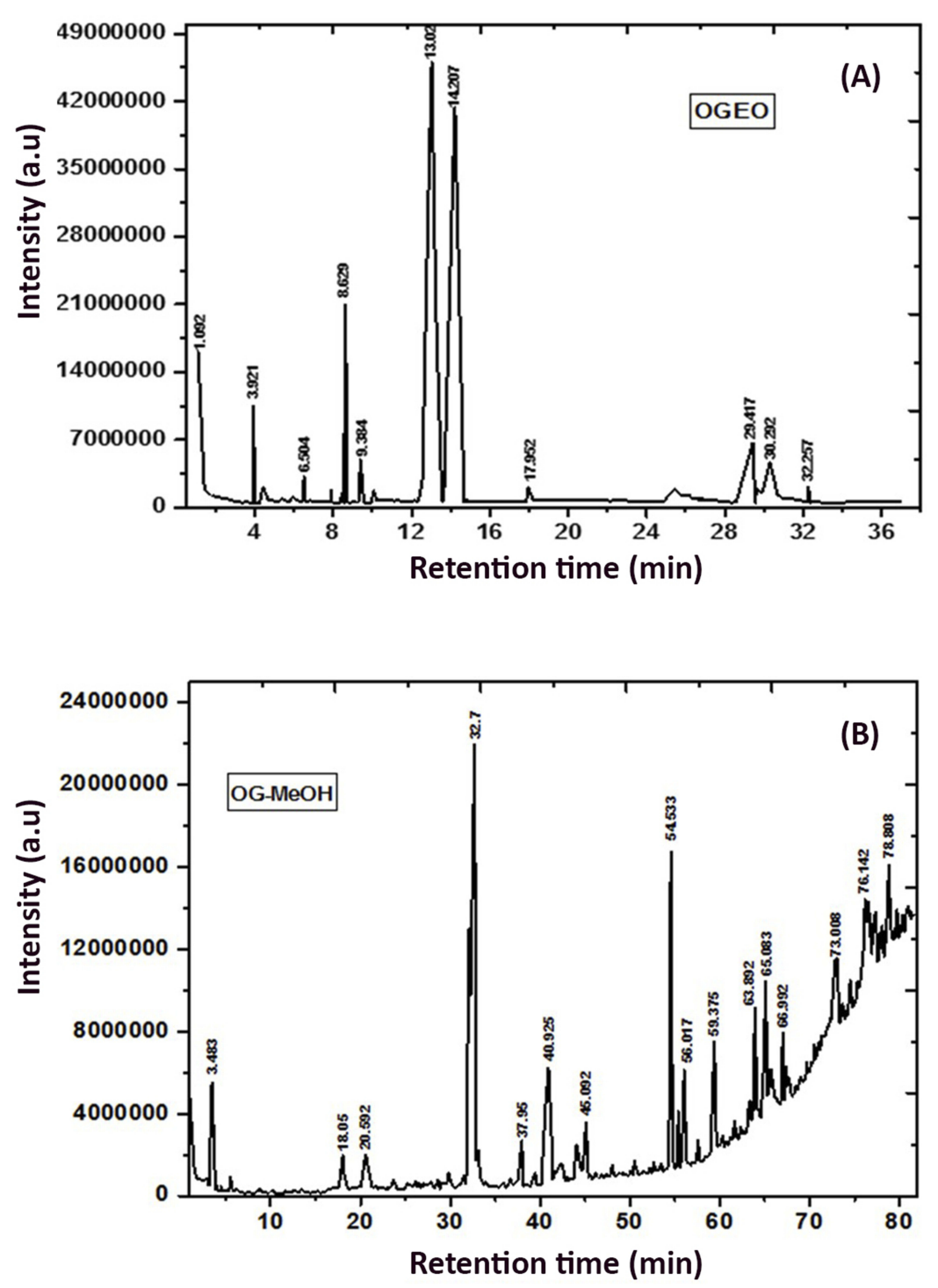

Figure 3 GC- MS chromatogram: (A) O. gratissimum essential oils and (B) methanolic extracts. Peak numbers refer to Tables I and 2, respectively.

and B). A total of 19 compounds were identified for OGEO (Table 1), while 35 compounds were identified for OGEO$\mathrm{MeOH}$ (Table 2). The chemical composition results indicate that OGEO contains more hydrocarbons, monoterpenes, and acids. Newly observed compounds that were not previously reported for OGEO were identified, including eicosane, heneicosane, triphenylphosphine oxide, 1-acetyl-2methyl-2cycloppentene, (E)-9-octadecenoic acid, 2-carene and gamma-terpinene. These new compounds might have been identified in this study due to the time of plant harvest, environmental factors, soil conditions, and plant age-all being factors that could affect the biochemical constituents of the plant extracts. ${ }^{30}$ While the identified compounds have known bioactivity, their applications are restricted due to their volatile nature. Hence, entrapment into polymeric matrices and a further reduction to nano sizes will surely increase their potential applications. ${ }^{12,13}$

\section{Total Phenolic Content}

Polyphenols are bioactive substances that are primarily associated with plants and essential oils in the human diet. A TPC determination is vital in order to ascertain the amount of antioxidants present in any plant. Dutta and Ray reported a positive correlation existing between phenolic and pharmacological activities such as antiviral, antimicrobial, anti-carcinogenic, anti-inflammatory and anti-allergic activities. ${ }^{31}$ The results of the TPC analysis (Table 3) indicate that the TPC of OGEO was $11.7 \pm$ $0.60 \mathrm{mg}$ GAE $/ 100 \mathrm{~g}$, which is greater than $(P<0.05)$ that of the $\mathrm{OG}-\mathrm{MeOH}$, which had a value of $1.4 \pm 0.45$ 
Table I Major Chemical Composition Of Ocimum Gratissimum Essential Oils (\%, Wt/wt) As Determined By Gas ChromatographyMass Spectrometry

\begin{tabular}{|l|l|l|l|}
\hline Component & Retention Time (min) & Content (\%, wt/wt) & Nature Of Compound \\
\hline Hexanoic acid & 1.092 & 5.61 & Acid \\
(E)-9-octadecenoic acid & 3.921 & 3.54 & Acid \\
7-Oxa-2-oxa-7-thiatricyclo[4.4.0.0(3,8)]decan-4-ol & 5.375 & 8.21 & Fatty alcohol \\
Oxanamide & 5.933 & 0.24 & Epoxide \\
Bicyclo[3.I.0]hex-2-ene, 4-methyl-I-(I-methylethyl) & 6.504 & 5.82 & Monoterpene \\
Beta-myrcene & 7.888 & 2.94 & Monoterpene \\
2-carene & 8.455 & 5.63 & Hydrocarbon \\
O-cymene & 8.629 & 4.51 & Hydrocarbon \\
Gamma-terpinene & 9.384 & 2.43 & Monoterpene \\
I-acetyl-2-methyl-2-cyclopentene & 10.067 & 3.6 & Ketone \\
Alpha-pinene & 12.55 & 14.31 & Terpene \\
Cis-ocimene & 12.825 & 12.46 & Monoterpene \\
Alpha-terpinolene & 13.025 & 0.73 & Terpene \\
$\alpha$-caryophyllene & 13.225 & 11.54 & Sesquiterpene \\
Thymol & 14.207 & 1.49 & Monoterpenoid \\
Beta-humulene & 17.952 & 1.53 & Sesquiterpene \\
Heneicosane & 29.417 & 2.46 & Hydrocarbon \\
Eicosane & 30.292 & 6.14 & Hydrocarbon \\
Triphenylphosphine oxide & 32.257 & 5.23 & Organophosphorus compound \\
\hline
\end{tabular}

mg GAE/100 g. Primary sources of antioxidants, antiviral, antibacterial and anti-inflammatory activities include various compounds such as cyanine, flavonoids, flavones, flavonols and phenols. ${ }^{31,32}$ Variations in the antioxidant activity of plants could be the result of the varying phenolic hydroxyl groups and polyphenolic compounds of any given plant. A study by Santana et al (2014) discovered $20 \%$ and $90 \%$ phenolic content in $O$. gratissimum leaves and stems, respectively. ${ }^{33}$ Olamilosoye et al also noted the phenolic content of $O$. gratissimum leaves to be $90.03 \mathrm{GAE} / 100 \mathrm{~g}^{34}$

\section{Characterisation Of $\mathrm{O}$. Gratissimum Free} EOs And EO-Loaded Nanoparticles Molecular Interaction Of OGEO With CSNPs And TMCNPs

The IR spectra for the various constituent compounds of the nanoparticles are presented in Figure 4. The sharp peak at $1387 \mathrm{~cm}^{-1}$ for the OGEO-TMCNPs and TMCNPs was assigned to the asymmetrical stretching of $\mathrm{C}-\mathrm{H}$ bonds of methyl groups existing in TMC. ${ }^{35}$

The peak at $1635 \mathrm{~cm}^{-1}$ for both the CS and TMC nanoparticles was attributed to the $\mathrm{C}=\mathrm{O}$ bonds of secondary amide groups related to the acetyl residues of TMC and CS nanoparticles. ${ }^{36}$ The band at $1402 \mathrm{~cm}^{-1}$ is assigned to the $\mathrm{OH}$ bend. ${ }^{37}$ The $2880 \mathrm{~cm}^{-1}$ band for the OGEO corresponded to methyl- $\mathrm{CH}$ stretch. ${ }^{10}$ The high intensity of the peak at 2880 for the OGEO-TMCNPs compared to the OGEO-CSNPs corresponds to an increase in the $\mathrm{N}$-alkyl group as a result of $\mathrm{N}, \mathrm{N}, \mathrm{N}$-trimethyl chitosan. ${ }^{38}$ Moreover, another band was identified at $1742 \mathrm{~cm}^{-1}$ for the OGEO, which is consigned to the methyne $\mathrm{C}-\mathrm{H}$ stretch. $^{11}$ The bands at $950 \mathrm{~cm}^{-1}$ and $918 \mathrm{~cm}^{-1}$ for OGEO correspond to the skeletal C-C vibrations. ${ }^{37}$ The successful encapsulation of OGEO into the TMCNPs and CSNPs is evident at $2880 \mathrm{~cm}^{-1}$ and $1089 \mathrm{~cm}^{-1}$, which are assigned to the methyl-CH stretch, $\mathrm{NH}$ bend and skeletal C-C vibrations, respectively. ${ }^{11}$ All four evaluated nanoparticles demonstrated the presence of $\mathrm{CS}$, including $\mathrm{OH}, \mathrm{CH}$ and $\mathrm{NH}$ stretch at $3000-3750 \mathrm{~cm}^{-1}$, and amides stretch at $1634 \mathrm{~cm}^{-1} .{ }^{10}$ The differences in the bend are due to the associations among chain segments of OGEO-CSNPs and OGEO-TMCNPs. The OGEO-loaded TMC nanoparticle spectra revealed the same peak as the free TMC nanoparticles, with the addition of extra peaks. Furthermore, an extra peak is also evident for the OGEO-loaded CS nanoparticles when compared to the free CS nanoparticles.

\section{Morphology Of OGEO-Loaded Nanoparticles}

The SEM images revealed an increase in the size of the OGEO-loaded CSNPs compared to free CSNPs (Figure 5A and $\mathrm{B})$. This is perhaps due to the encapsulation of the EOs 
Table 2 Chemical Composition Of Ocimum Gratissimum Methanolic Extract (\%, Wt/wt) As Determined By Gas Chromatography-Mass Spectrometry

\begin{tabular}{|c|c|c|c|}
\hline Chemical Name & $\begin{array}{l}\text { Retention } \\
\text { Time (min) }\end{array}$ & $\begin{array}{l}\text { Content } \\
(\%, w t / w t)\end{array}$ & $\begin{array}{l}\text { Nature Of } \\
\text { Compound }\end{array}$ \\
\hline Glycerine & 3.350 & 3.3 & Polyol compound \\
\hline I,2,3,4-butanetetrol & 3.483 & 0.64 & Unknown \\
\hline M-cymene & 18.050 & 3.9 & Hydrocarbon \\
\hline 2-pentanoic acid, 4-hydroxy & 20.400 & 0.63 & Alkyl carboxylic acid \\
\hline $\mathrm{N}$-acetyl-proline & 29.808 & 2.62 & Proline \\
\hline Trans-(+)-carveol & 31.542 & 0.53 & Monoterpenoid \\
\hline Phenol, 5-methyl-2-(I-methylethyl)- (CAS) Thymol & 32.700 & 0.42 & Monoterpenoid phenol \\
\hline Phenol, 2-methyl-5-(I-methylethyl)- (CAS) Carvacrol & 32.917 & 9.56 & Monoterpenoid phenol \\
\hline B-caryophyllene & 37.950 & 4.21 & Sesquiterpene \\
\hline (E)-farnesene & 39.467 & 1.02 & Sesquiterpene \\
\hline$(+)$-longifolene & 40.925 & 0.79 & Tricyclic sesquiterpene \\
\hline$(+)$-aromadendrene & 41.292 & 6.25 & Tricyclic hydrocarbon \\
\hline Alpha-cedrol & 42.267 & 3.41 & Sesquiterpene alcohol \\
\hline Germacrene-d & 42.458 & 0.13 & Sesquiterpene \\
\hline Phenol, 2-(I,I-dimethylethyl)-6-methyl- (CAS) 6-tert-butyl-o-cresol & 44.042 & 1.42 & Aromatic compound \\
\hline Aromadendrene epoxide-(ii) & 47.875 & 0.76 & Sesquiterpenoid \\
\hline 25,26-Dihydroxy-vitamin D3 & 52.650 & 0.32 & Steroid \\
\hline 9-eicosyne & 54.533 & 0.67 & $\begin{array}{l}\text { Terminal alkynes } \\
\text { (hydrocarbon) }\end{array}$ \\
\hline Phytol & 55.383 & 2.65 & Diterpene alcohol \\
\hline Citronellyl pentanoate & 55.750 & 3.53 & Fatty alcohol ester \\
\hline Pentadecanoic acid, I4-methyl-, methyl ester (CAS) methyl I4-methyl-pentadecanoate & 57.575 & 3.46 & Fatty acid \\
\hline 9-Octadecenoic acid (Z)- (CAS) Oleic acid & 59.375 & 0.21 & Fatty acid \\
\hline Ialpha,25-dihydroxy vitamin D3 (CAS) Calcitriol & 60.342 & 5.78 & Steroid \\
\hline Cholesteryl myristate & 61.633 & 0.87 & Steroid ester \\
\hline Kauren-18-ol, acetate, (4. beta.)- (CAS) & 63.133 & 1.48 & Diterpenoids \\
\hline 2-monolinolenin & 63.342 & 1.49 & Fatty acyls \\
\hline Ethyl linoleate & 65.083 & 1.53 & Ester \\
\hline Cholesterin palmitate & 65.633 & 2.46 & Ester \\
\hline Cycloeucalenone & 65.933 & 0.14 & Steroid \\
\hline Flavone 4'-oh,5-oh,7-di-o-glucoside & 66.992 & 5.23 & Flavonoid \\
\hline Androst-5-en-7-one, 3-(acetyloxy)-4,4-dimethyl-, (3.beta)- (CAS) & 67.300 & 3.65 & Steroid ester \\
\hline Solanesol & 67.592 & 7.32 & Hydrocarbon \\
\hline Tetracosapentaene, 2,6,10,15,19,23-hexamethyl- (CAS) Dihydrosqualene & 72.800 & 4.87 & Unknown \\
\hline Nerolidol & 72.933 & 6.9 & Sesquiterpene \\
\hline $\begin{array}{l}\text { I. IH-3a,7-Methanoal H-3a,7-Methanoazulen-6-ol, octahydro-3,6,8,8-tetramethyl-, } \\
\text { [3R-(3.alpha.,3a.beta.,6.alpha.,7.beta.,8a.alpha.)]- (CAS) Cedrol }\end{array}$ & 73.500 & 5.4 & Sesquiterpene alcohol \\
\hline
\end{tabular}

Table 3 Total Phenolic Content Of O. Gratissimum Essential Oils And Methanolic Extract

\begin{tabular}{|l|l|l|}
\hline S/N & Compound & TPC $(\mathbf{m g}$ GAE/I00 g) \\
\hline 1 & OGEO & $11.7 \pm 0.60^{\mathrm{a}}$ \\
2 & OG-MeOH & $1.4 \pm 0.45^{\mathrm{b}}$ \\
\hline
\end{tabular}

Notes: ${ }^{2}$ Values given are averages of three replicates $(n=3) \pm$ standard deviations. Total phenolic content average values with differing superscript letters (within columns) indicate significantly different values $(P \leq 0.05)$.

into the nanoparticles' internal core. Woranuch and Yoksan likewise detailed an expansion in the size of nanoparticles due to the encapsulation of EOs. ${ }^{39}$ Notably, the surface of the TMCNPs appeared smoother compared to the OGEOTMCNPS (Figure 5C and D), which could be the result of EOs becoming attached to the TMCNP surface. ${ }^{40}$ Malik et al also reported the smooth and irregular shape of antigenloaded TMCNPs. ${ }^{22}$ The sizes of the OGEO-TMCNPs conformed to those reported by Sotelo-Boyás et $\mathrm{al}^{10}$. According to Lai et al, the average size distribution of nanoparticles is a function of the method of nanoparticle synthesis and other experimental conditions. ${ }^{41}$ 


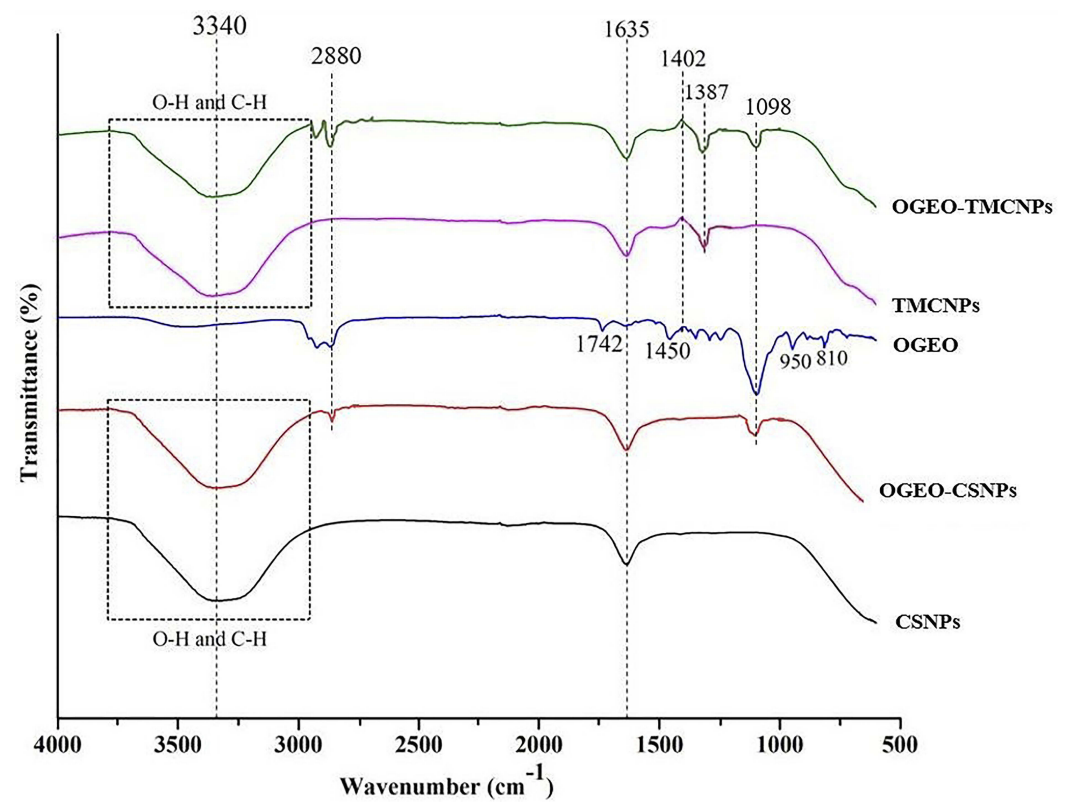

Figure 4 FTIR spectra of chitosan and N, N, N-trimethyl chitosan nanoparticles, free OGEO and OGEO-loaded nanoparticles. Abbreviation: FTIR, Fourier-transform infrared spectroscopy.

\section{Nanoparticles Diameter, Zeta Potential And Polydispersity Index (PDI)}

The size distribution of nanoparticles containing OGEOs is presented in Table 4. The results revealed that the polydispersity index, which is a measure of the uniformity in size distribution, were in an adequate range $(0.256 Ð-0.392 Ð)$. This demonstrates the uniformity, stability and monodispersity of the nanoparticles (Figure S1) ${ }^{42}$ According to results, free CSNPs had a smaller size $(150.1 \pm 4.02 \mathrm{~nm})$ compared to other formulations.

Zeta potential values for the nanoparticles were determined for $\mathrm{CSNP}_{\mathrm{S}}(24.0 \pm 0.9)$, TMCNPs $(19.2 \pm 0.1)$, OGEOTMCNPs (22.6.293 \pm 0.2$)$ and OGEO-CSNPs (26.10.288 \pm 1.0 ), respectively. Based on statistical analysis, the addition of EOs to the nanoparticles resulted in a significant increase ( $P$ $<0.05)$ in the zeta potential values for OGEO-encapsulated nanoparticles. This conforms to the results of Zhang et al regarding increased zeta potential values resulting from drug loading. ${ }^{43}$ Although the zeta potential values determined for the nanoparticle were between $19-27 \mathrm{mV}$, the nanoparticles were stable with no form of aggregation. Furthermore, the percentage encapsulation efficiency (EE) of OGEO-CSNPs and OGEO-TMCNPs were within an acceptable range of $61.1 \pm 1.67 \%$ and $69.4 \pm 0.85 \%$, respectively. Similar to a study by Li et al, the size of the synthesised nanoparticle in the present study has potential application in pharmaceutical and food industries. ${ }^{27}$

\section{Nanoparticle Encapsulation Efficiency (EE) And Loading Capacity (LC)}

The drug loading capacity and EE of the OGEO-loaded CS and TMC nanoparticles are presented in Figure 6. For OGEO-loaded CS nanoparticles, there was an upsurge in EE (42.54\%) and LC (18.42\%) among OGEO-CSNPs at an oil-CSNP ratio of 0.05:1 (w/w), as shown in Figure 6A. However, there was a drastic reduction in EE and LC for OGEO-CSNPs as oil ratio $(\mathrm{w} / \mathrm{w})$ increased. This can be as a result of the saturation of OGEO loading into chitosan nanoparticles. These findings are in line with a study by Yoksan et $\mathrm{al}^{44}$ For the OGEO-TMCNPs, the LC and EE were initially within the range of $27.71 \%$, and $55.87 \%$ respectively. As OGEO amount increased, LC and EE decreased (see Figure 6B). In addition, Hossein et al reported a decrease in the EE and LC of CS nanoparticles as the concentration of essential oil increased. ${ }^{14}$ An increase in oil: CS weight ratio resulted in a significant difference for both the LC and EE $(P<0.05)$. OGEO-TMCNPs had higher $(P<0.05) \mathrm{EE}$ and LC values with a corresponding increase in OGEO concentration compared to the OGEO-CSNPS. This indicates that the concentration of OGEO had a significant $(P<0.05)$ effect on the EE and LC of the nanoparticles. This trend also conforms with other studies on the encapsulation of EOs with polymeric materials. ${ }^{10,45}$ 
(A)

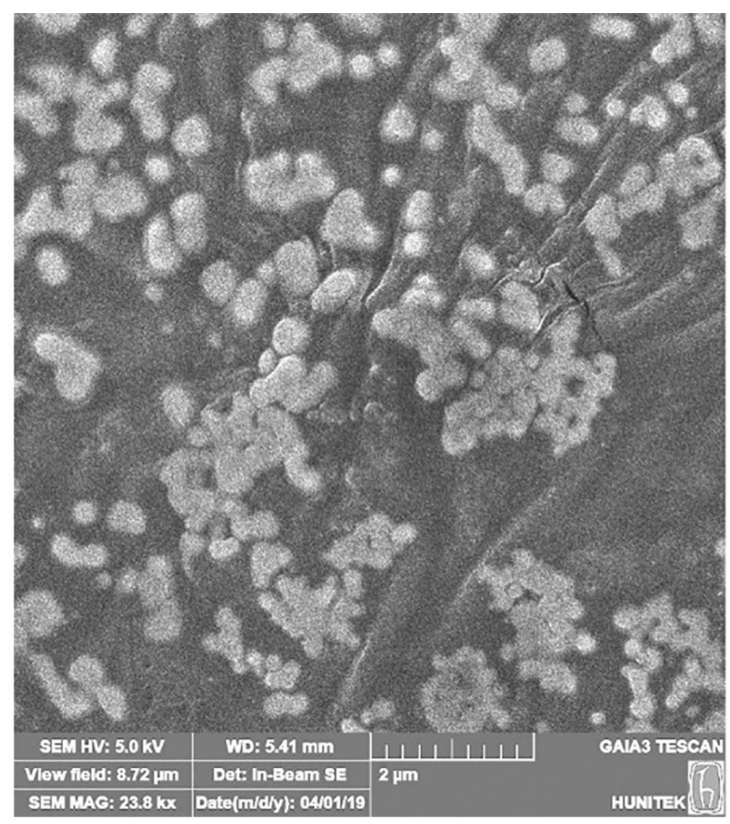

(C)

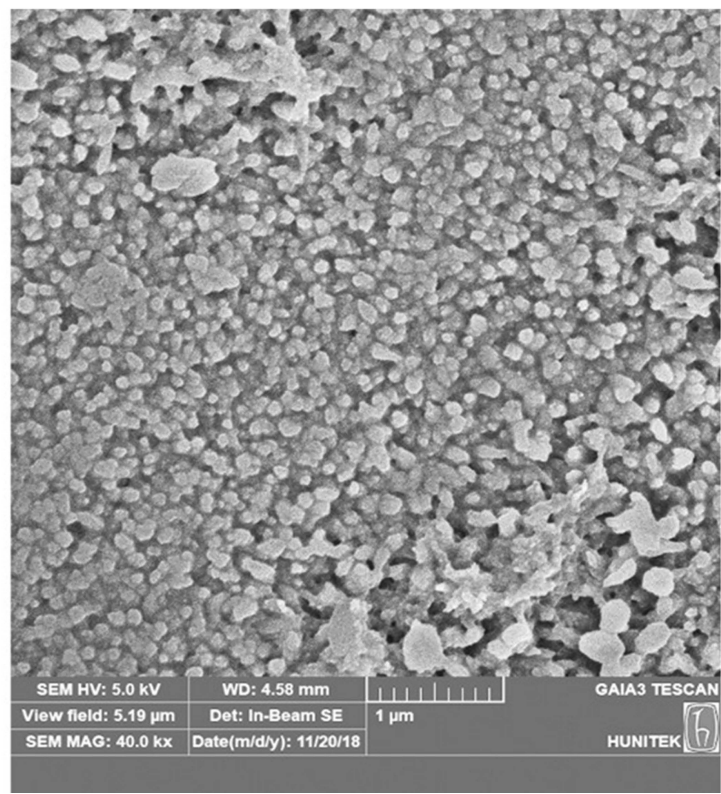

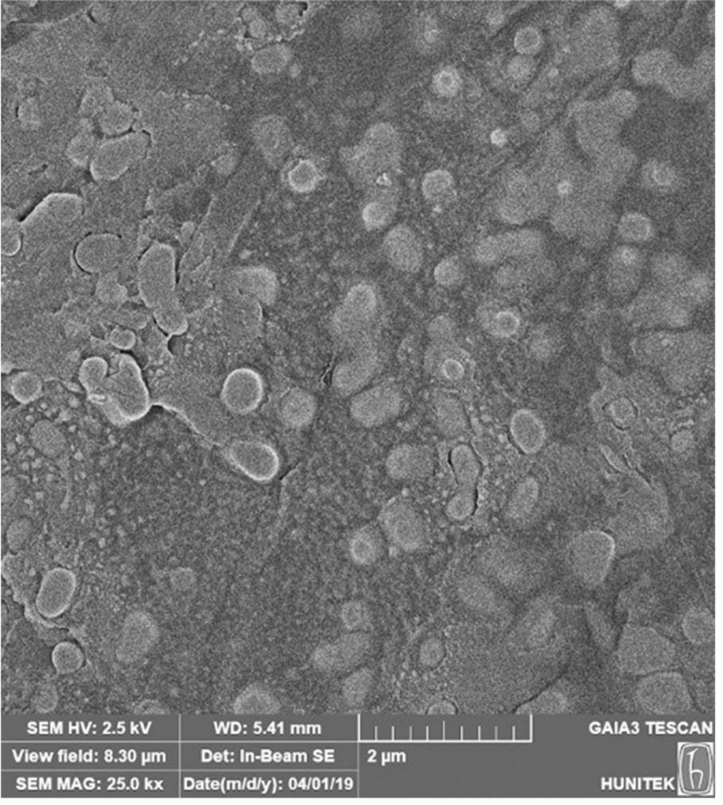

(B)

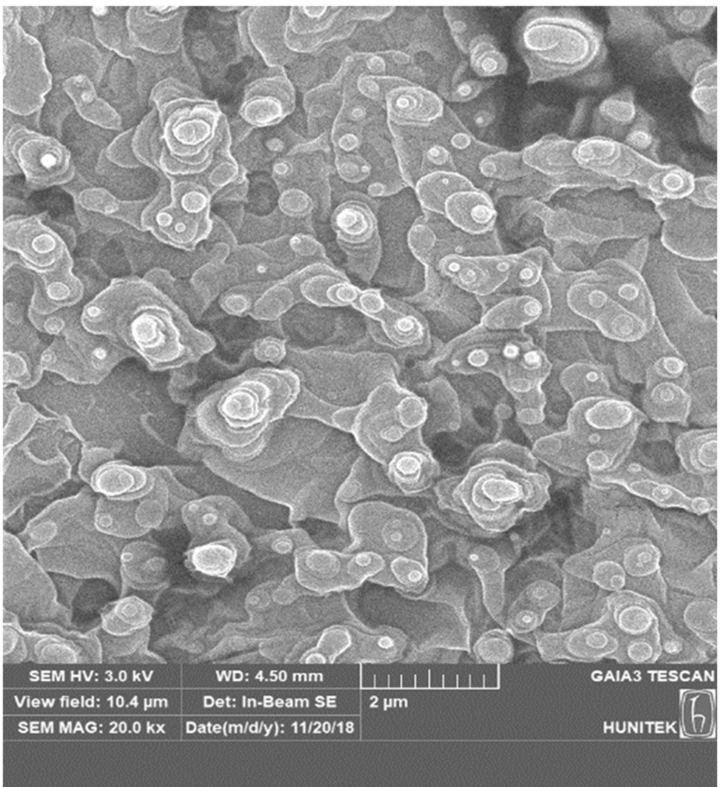

(D)

Figure 5 SEM images: (A) free chitosan nanoparticles, (B) OGEO-loaded chitosan nanoparticles (C) free N, N, N-trimethyl chitosan nanoparticles and (D) OGEO-loaded $\mathrm{N}, \mathrm{N}, \mathrm{N}$-trimethyl chitosan nanoparticles.

Abbreviations: SEM, scanning electron microscope; OGEO, Ocimum gratissimum essential oils.

\section{In Vitro O. Gratissimum Essential Oil Release And Kinetic Modelling}

The effect of $\mathrm{pH}$ on essential oil release from the $\mathrm{CS}$ and TMC nanoparticles at an optimum EO to nanoparticle loading ratio $(w / w)$ is shown in Figure 7. The release of OGEO from the nanoparticles was higher at $\mathrm{pH} 3.0$ than at $\mathrm{pH}$ 7.4. This is as a result of the bulging of nanoparticles in acidic media, thereby leading to a higher EO release, ${ }^{46}$ with $64.19 \%$ and $48.45 \%$ cumulative EO release being observed for OGEO-TMCNPs and OGEO-CSNPs, respectively, at $\mathrm{pH}$ 7.4. At $\mathrm{pH}$ 3.0, cumulative EO release for OGEO-TMCNPs and OGEOCSNPs were $77.35 \%$ and $70.39 \%$, respectively. Malik et al reported a $30 \%$ protein release at $\mathrm{pH} 7.4$ after $6 \mathrm{~h}$ with an increase to $55 \%$ within the first $24 \mathrm{~h}$ and reaching a steady state release after $48 \mathrm{~h}^{22}$ OGEO-TMCNPs exhibited higher EO release at all $\mathrm{pH}$ conditions compared to the OGEO-CSNPs. This is the result of the increased EO loading capacity of TMC nanoparticles with the influence of the methyl group. In alkaline mediums, the chitosan amino group protonation increases the stability of the nanoparticles, thereby resulting in slower 
Table 4 Particle Diameter, Zeta Potential And Polydispersity Index (PDI) Of The Optimised OGEO-Loaded CS And TMC Synthesised Nanoparticles

\begin{tabular}{|c|c|c|c|c|}
\hline Nanoparticles & $\begin{array}{l}\text { Z-average } \\
\text { Diameter } \pm D \\
(\mathrm{~nm})\end{array}$ & PDI $\pm D$ & Zeta Potential $\pm D(\mathrm{mV})$ & Encapsulation Efficiency (\%) \\
\hline CSNPs & $50.1 \pm 4.02^{\mathrm{a}}$ & $0.256 \pm 0.0 \mathrm{I}^{\mathrm{a}}$ & $24.0 \pm 0.9^{\mathrm{a}}$ & - \\
\hline TMCNPs & $84.3 \pm 6.5 \mathrm{I}^{\mathrm{b}}$ & $0.312 \pm 0.09^{b}$ & $19.2 \pm 0.1^{b}$ & - \\
\hline OGEO-CSNPS & $134.9 \pm 6.73^{\mathrm{d}}$ & $0.288 \pm 0.07^{d}$ & $26.1 \pm 1.0^{d}$ & $61.1 \pm 1.67$ \\
\hline OGEO-TMCNPs & $153.5 \pm 10.48^{c}$ & $0.293 \pm 0.29^{c}$ & $22.6 \pm 0.2^{c}$ & $69.4 \pm 0.85$ \\
\hline
\end{tabular}

Notes: Reported means ( \pm standard deviations) derived from three replications with three samples per replication. Means within each column are followed by different superscripts are significantly different at $p \leq 0.05$.
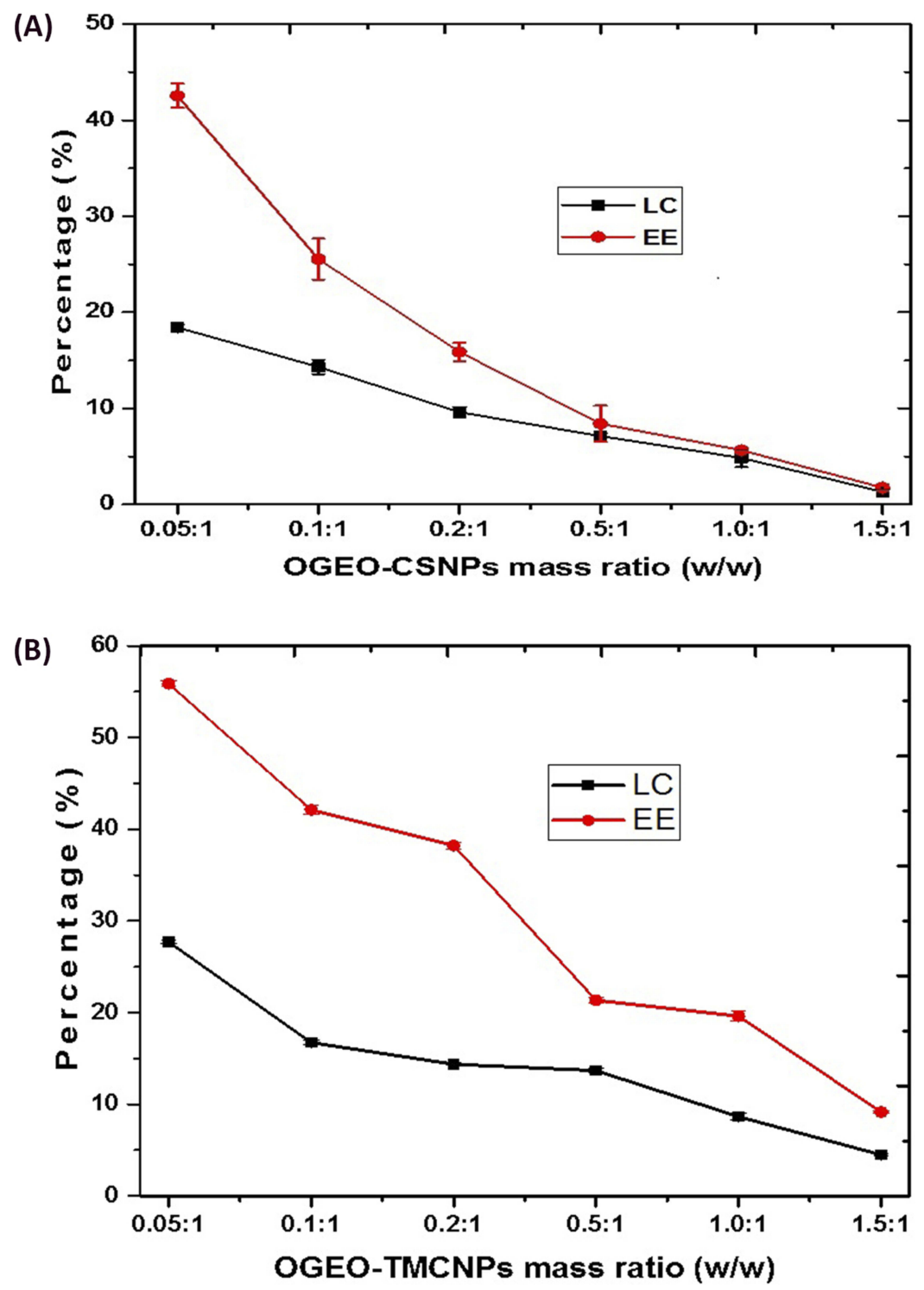

Figure 6 Loading capacity (LC) and encapsulation efficiency (EE): (A) O. gratissimum essential oil-loaded chitosan nanoparticles, (B) O. gratissimum essential oil-loaded N, N, $\mathrm{N}$-trimethyl chitosan. Bars represent means \pm standard deviation.

Abbreviations: OGEO-CSNPs, Ocimum gratissimum essential oil-loaded chitosan nanoparticles; OGEO-TMCNPs, Ocimum gratissimum essential oil-loaded trimethyl chitosan nanoparticles. 

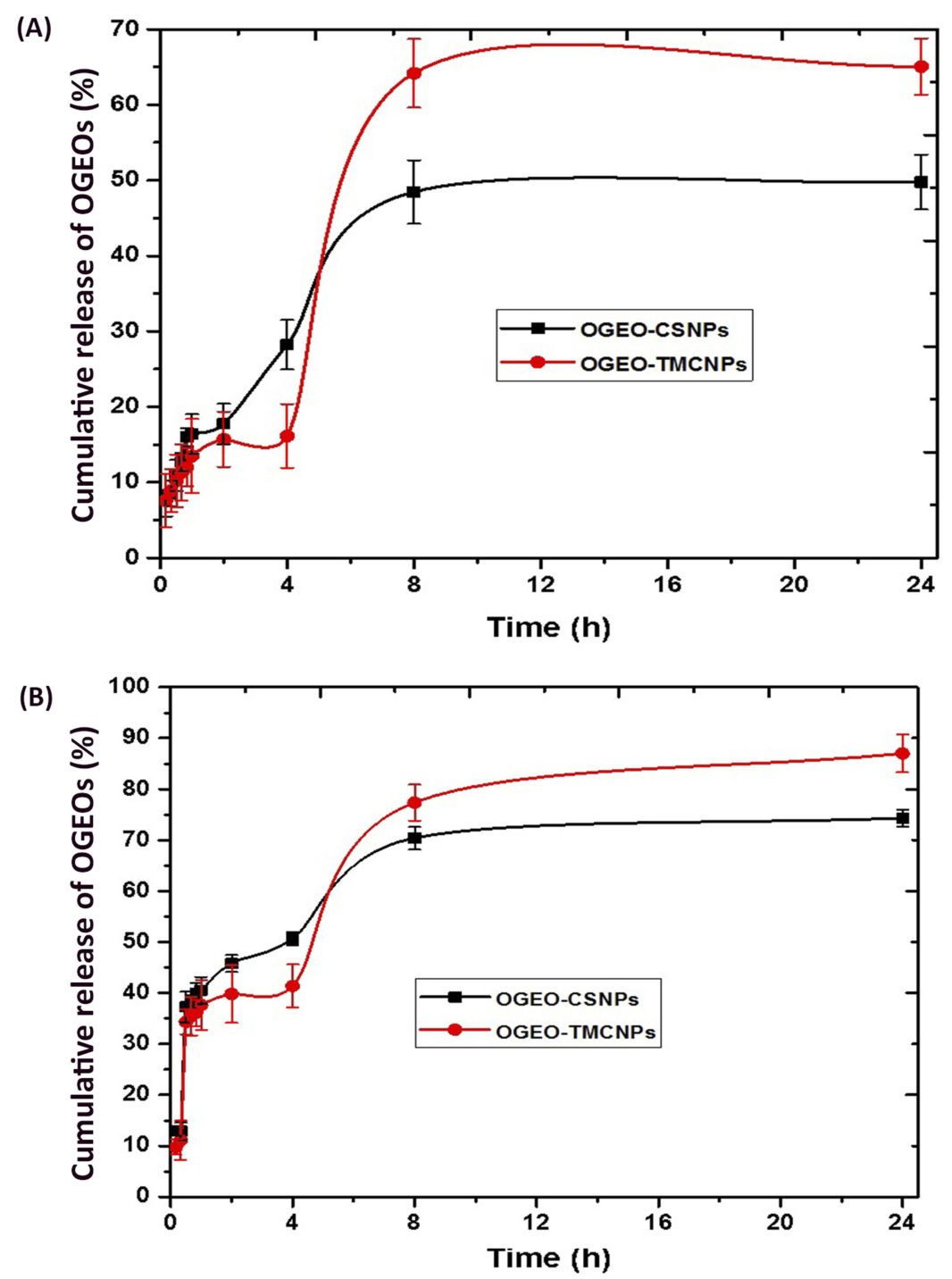

Figure 7 Percentage cumulative in vitro release of 0 . gratissimum essential oils from chitosan and $\mathrm{N}, \mathrm{N}, \mathrm{N}$ - trimethyl chitosan nanoparticles: (A) $\mathrm{pH} 7.4$ (B) $\mathrm{pH}$ 3.0. (Bars represent means \pm standard deviation).

Abbreviations: OGEO-CSNPs, Ocimum gratissimum essential oil-loaded chitosan nanoparticles; OGEO-TMCNPs, Ocimum gratissimum essential oil-loaded trimethyl chitosan nanoparticles.

drug release. ${ }^{5}$ Also, there was a significant increase in the release rate of OGEO from the TMC nanoparticles over a longer time period, which might be due to a chemical interaction between OGEO and TMC functional groups. It should be noted that the release profiles of OGEO from the TMC nanoparticles were not complete; therefore, there is a need for the complete degradation of TMC nanoparticles. ${ }^{47,48}$ Moreover, the release of OGEO from the nanoparticles at all tested physiological $\mathrm{pH}$ can be regarded as a two-step biphasic process due to an initial burst release with a subsequent slower release. ${ }^{14}$ This type of release as expressed by Anitha et al is the result of the attachment of EO on the nanoparticles' surface. ${ }^{49}$
The release profile of OGEO was applied to different kinetic models, including the zero-order, KorsmeyerPeppas, first-order, and Higuchi models for different $\mathrm{pH}$ media ( $\mathrm{pH} 3$ and $\mathrm{pH}$ 7), as shown in Figures 8 and 9. As presented in Table 5, the regression value for zero-order kinetics $\left(\mathrm{r}^{2}\right)$ for both OGEO-loaded CS and TMC nanoparticles were moderate at all physiological $\mathrm{pH}$ conditions (0.557-0.799). This reveals that the drug release kinetic pattern is not well suited to the zero-order model. Also, for the Huguchi and first-order models, the $r^{2}$ value was below 0.79 for OGEO-CSNPs and OGEO-TMCNPs at all $\mathrm{pH}$ ranges. The best $r^{2}$ values were observed with the 

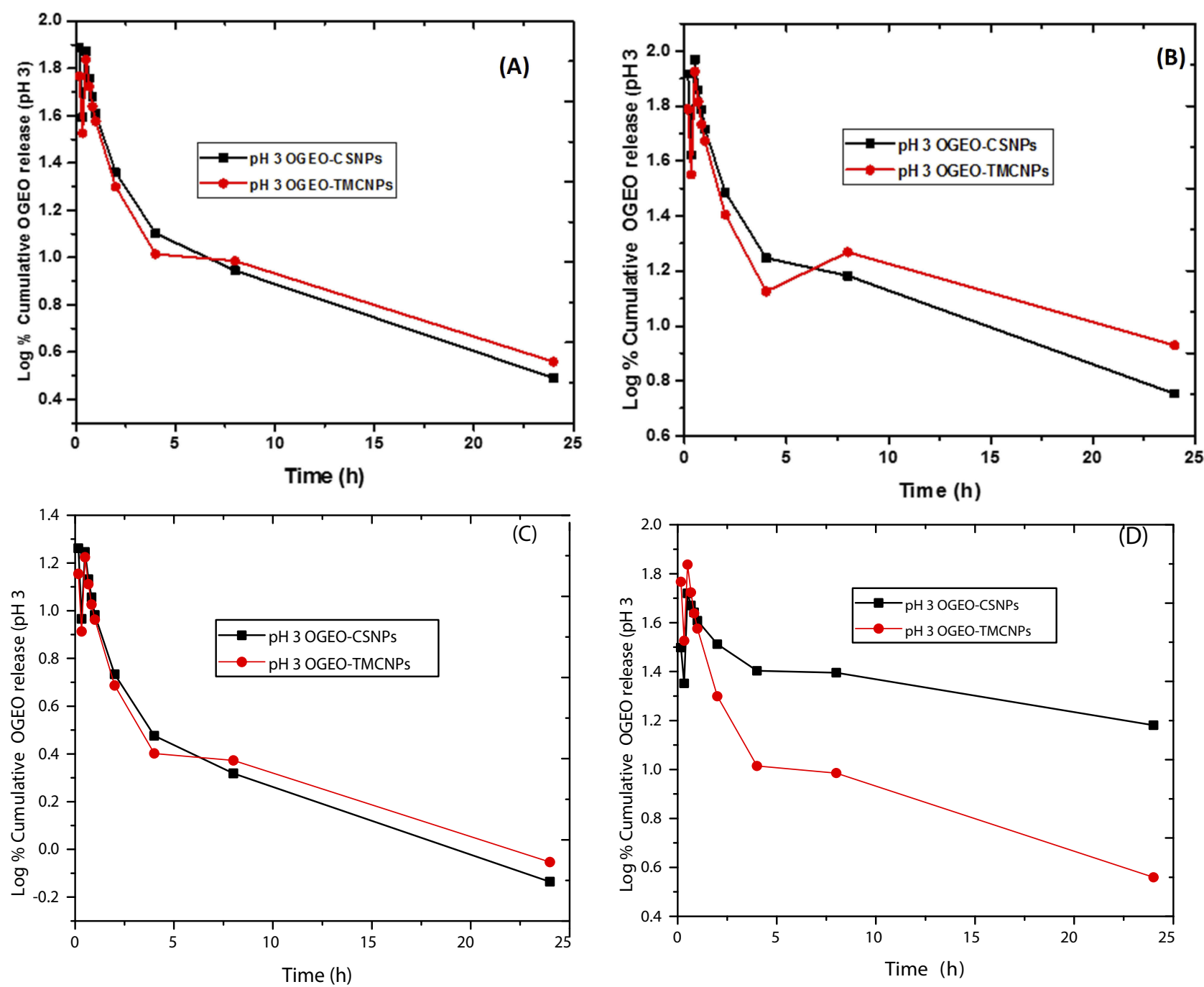

Figure 8 Kinetic models for OGEO release from chitosan and N, N, N-trimethyl chitosan nanoparticles at pH 3 (A) Zero-order, (B) First-order, (C) Korsmeyer - Peppas and (D) Higuchi model.

Abbreviations: OGEO-CSNPs, Ocimum gratissimum essential oil-loaded chitosan nanoparticles; OGEO-TMCNPs, Ocimum gratissimum essential oil-loaded trimethyl chitosan nanoparticles.

Korsmeyer-Peppas model for both OGEO-CSNPs and OGEO-TMCNPs in different $\mathrm{pH}$ media (pH 3.0 and $\mathrm{pH} 7.4$ ).

\section{DPPH Radical Scavenging Activity Assay}

The antioxidant activity of compounds in line with assertions by previous studies is evaluated activity after $30 \mathrm{mins}$ exposure of the compound to DPPH solution. ${ }^{50}$ However, Kamimura et al suggests that antioxidant activity is likely to continue over a longer period due to the unpredictable oxidation kinetics of different compounds over time. ${ }^{51}$

At the initial stages $(1-5 \mathrm{~h})$, the antioxidant property of free OGEO was higher $(P<0.05)$ compared to both the OGEO-MeOH and the nanoparticles. Free OGEO reached consistency after $10 \mathrm{~h}$ of exposure time. Even after $75 \mathrm{~h}$, CSNPs and TMCNPs scavenging ability never reached consistency (Figure 10). The higher antioxidant activity of OGEO-encapsulated TMCNPs and CSNPs is attributed to the synergistic effort between OGEOs, TMCNPs, and CSNPs. The findings of this study are in agreement with the results of Zhang et al, which note that even at low concentrations, TMC shows high antioxidant activity, with a scavenging rate up to 95\% higher than CS. ${ }^{52}$

\section{Antibacterial Activity Of $O$. Gratissimum, Methanolic Extract, EOs, And EO-Loaded Nanoparticles}

Figure 11 presents the antibacterial activity of the free OGEO and OGEO-MeOH as well as the OGEO-loaded nanoparticles. Based on the results, the antibacterial 

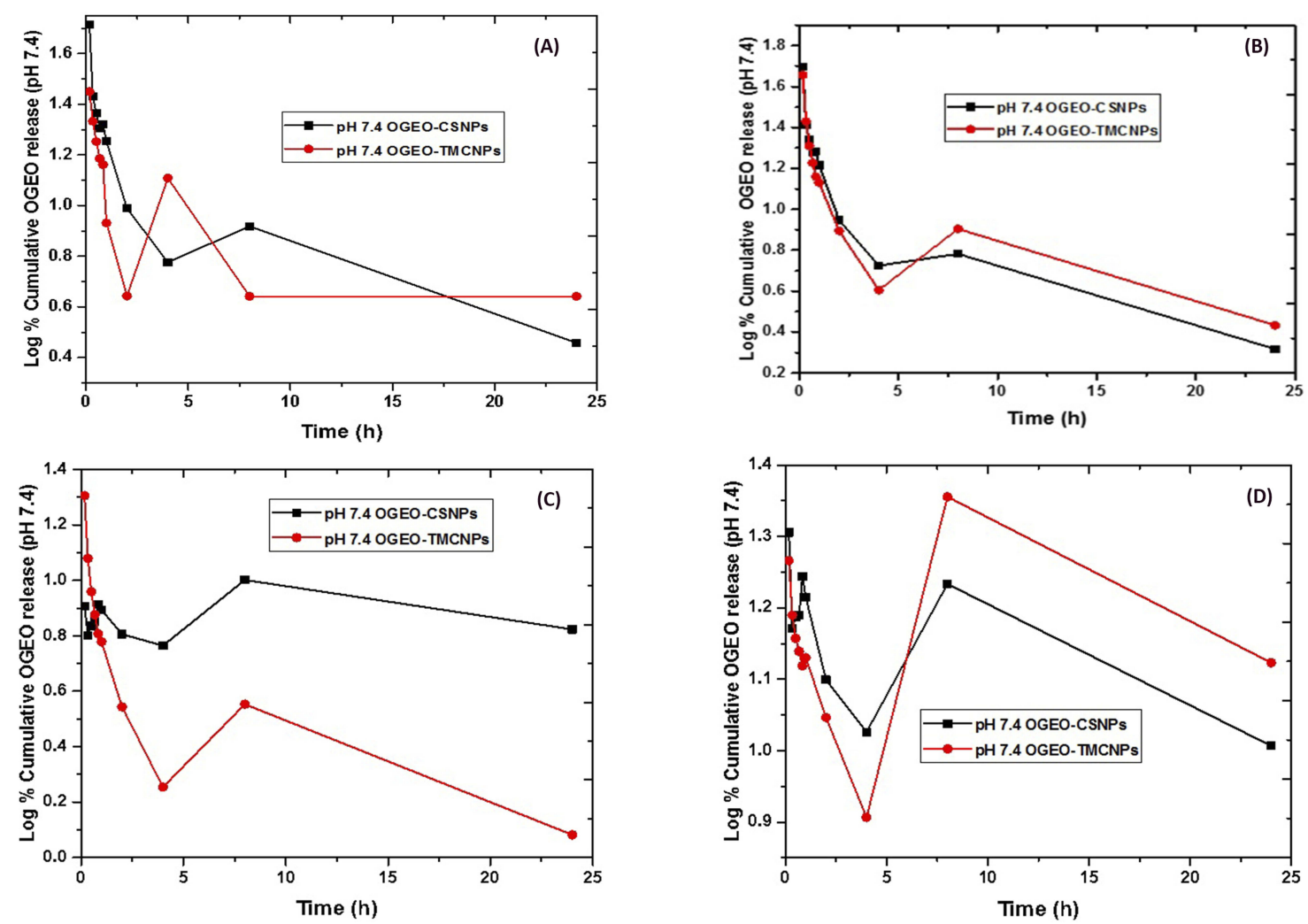

Figure 9 Kinetic models for OGEO release from chitosan and N, N, N-trimethyl chitosan nanoparticles at pH 7.4: (A) zero-order, (B) first-order, (C) Korsmeyer-Peppas and (D) Higuchi model.

Abbreviations: OGEO-CSNPs, Ocimum gratissimum essential oil-loaded chitosan nanoparticles; OGEO-TMCNPs, Ocimum gratissimum essential oil-loaded trimethyl chitosan nanoparticles.

Table 5 Kinetic Data Of OGEOO Release From Chitosan And Trimethyl Chitosan Nanoparticles In Different Physiological pH Mediums (ph 3.0 And $\mathrm{pH} 7.4$ )

\begin{tabular}{|l|l|l|l|l|l|l|l|l|}
\hline \multirow{2}{*}{ Samples } & \multicolumn{2}{l}{ Zero-Order } & \multicolumn{2}{l|}{ First-Order } & \multicolumn{2}{l|}{ Korsmeyer-Peppas } & \multicolumn{2}{l|}{ Higuchi } \\
\cline { 2 - 8 } & $\mathbf{r}^{2}$ & $\mathbf{K}_{\mathbf{0}}$ & $\mathbf{r}^{2}$ & $\mathbf{K}_{\mathbf{l}}$ & $\mathbf{r}^{\mathbf{2}}$ & $\mathbf{K}_{\mathbf{K P}}$ & $\mathbf{r}^{\mathbf{2}}$ & $\mathbf{K}_{\mathbf{H}}$ \\
\hline OGEO-CSNPs (pH 3.0) & 0.792 & 1.657 & 0.772 & 1.746 & 0.792 & 1.031 & 0.565 & 1.569 \\
OGEO-TMCNPs (pH 3.0) & 0.749 & 1.596 & 0.624 & 1.668 & 0.749 & 0.983 & 0.749 & 1.596 \\
OGEO-CSNPs (pH 7.4) & 0.699 & 1.289 & 0.661 & 1.320 & 0.0014 & 0.861 & 0.371 & 1.200 \\
OGEO-TMCNPs (pH 7.4) & 0.557 & 1.231 & 0.398 & 1.142 & 0.557 & 0.981 & 0.001 & 1.143 \\
\hline
\end{tabular}

Notes: Where the regression coefficient is $r^{2}$, release rate constant for zero-order is $K_{0}$, release rate constant for first-order is $K_{1}$, Korsmeyer-Peppas rate constant is $K_{K P}$ and Higuchi rate constant is $\mathrm{K}_{\mathrm{H}}$.

activity of OGEOs, OGEO-MeOH, CSNPs, TMCNPs, OGEO-CSNPs and OGEO-TMCNPs at respective MBC values of $150,150,200,100,60$ and $40\left(\mathrm{mg} \mathrm{mL}^{-1}\right)$, respectively, exhibited considerable antibacterial activity on agar plates. Notably, OGEO-TMCNPs showed the highest $(P<0.05)$ zone of inhibition (Figure 12). The enhanced antibacterial activity of the OGEO-TMCNPs is both the contribution of OGEO and TMCNPs, with
TMCNPs enhancing the permeability across the microbial cell wall. $^{53}$

The results of the present study are in line with previous studies on the antibacterial properties of EOs against foodborne pathogens such as $S$. typhimurium, E. coli, and Listeria monocytogens. ${ }^{15,54}$ However, complete clarity on the antibacterial mode of action of nanoparticles of chitosan and its derivatives remain elusive. 


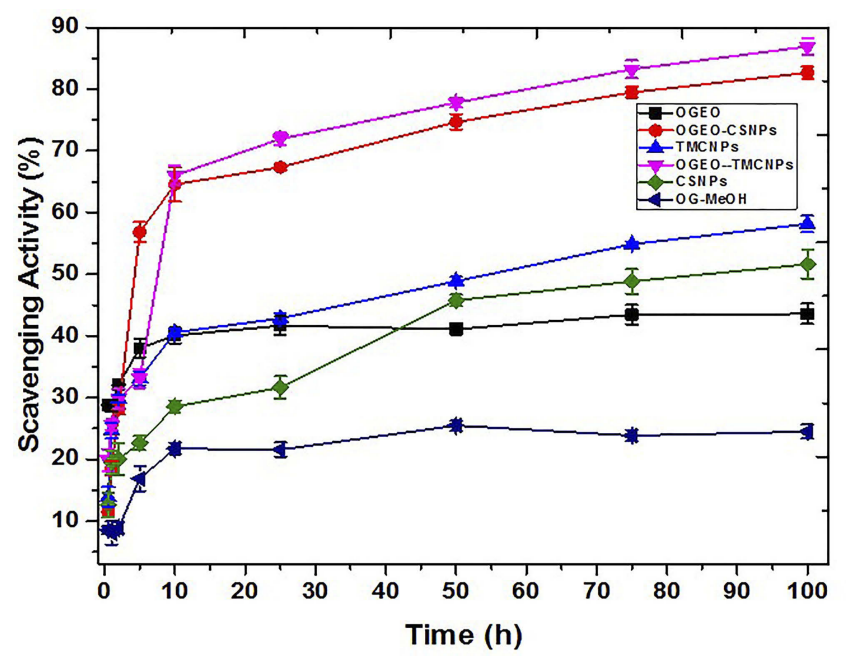

Figure 10 DPPH scavenging activity assay of $O$. gratissimum EOs, methanolic extracts, chitosan and N, N, N-trimethyl chitosan nanoparticles, and EO-loaded chitosan and $\mathrm{N}$, $\mathrm{N}, \mathrm{N}$-trimethyl chitosan nanoparticles. (Bars represent means \pm standard deviations).

Abbreviations: OGEO, Ocimum gratissimum essential oils; OG-MeOH, Ocimum gratissimum methanolic extract; CSNPs, chitosan nanoparticles; TMCNPs, trimethyl chitosan nanoparticles.
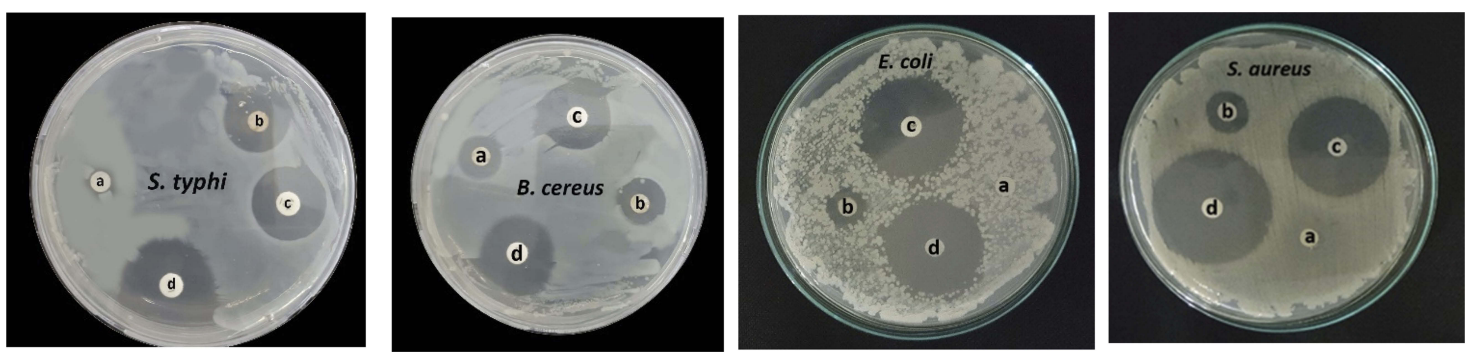

Figure II The zones of inhibition for OGEO-loaded nanoparticles compared with antibiotics: (A) OGEO-CSNPs, (B) OGEO-TMCNPs, (C) ampicillin, and (D) chloramphenicol. Abbreviations: OGEO, Ocimum gratissimum essential oils; CSNPs, chitosan nanoparticles; TMCNPs, trimethyl chitosan nanoparticles.

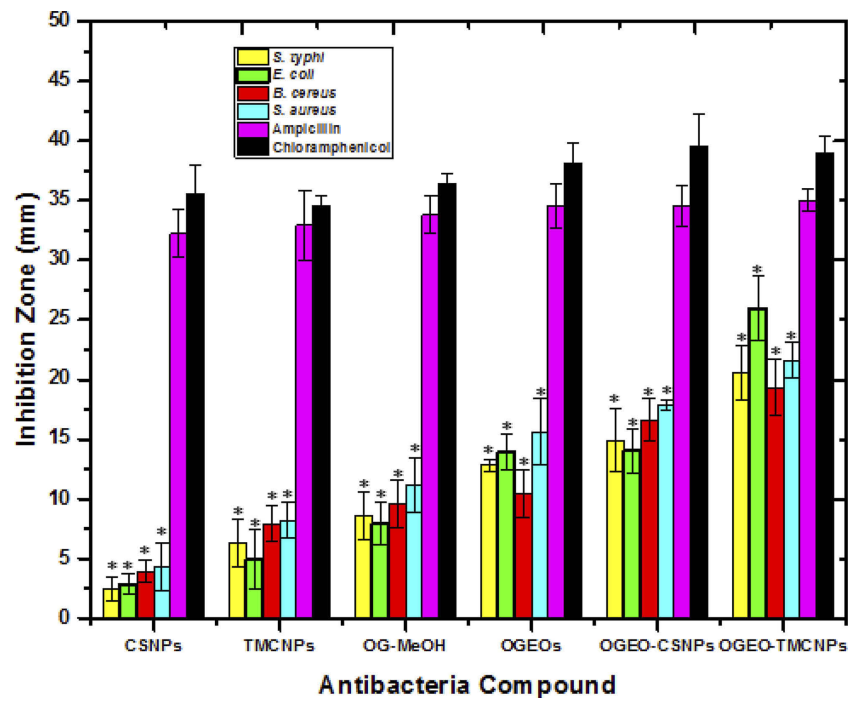

Figure 12 Antimicrobial disc diffusion results for 0 . gratissimum EOs, methanolic extracts, and nanoparticles. (Columns and bars represent means \pm standard deviation) * the antibacterial statistical difference $(P \leq 0.05)$ between controls (ampicillin and chloramphenicol) and $O$. gratissimum methanolic extract, EOs and nanoparticles.

Abbreviations: OGEO, Ocimum gratissimum essential oils; OG-MeOH, Ocimum gratissimum methanolic extract; CSNPs, chitosan nanoparticles; TMCNPs, trimethyl chitosan nanoparticles. 
Notably, some studies have speculated that the antibacterial activity of nanoparticles of CS and their derivatives are the result of cell porousness and interactions between the $\mathrm{NH}_{2}$ group in $\mathrm{CS}$ and the electromagnetic charge on the cell wall of bacteria. ${ }^{47}$ The antibacterial activity of CS nanoparticles is also due to the disruption of the cytoplasm due to the penetration of CSNPs through the microbial cell wall. ${ }^{55}$

\section{Antiproliferative Activity Of $O$. Gratissimum, Methanolic Extract, EOs And EO-Loaded Nanoparticles}

The cell viability and antiproliferation of a strongly metastatic breast cancer cell line (MDA-MB-231 breast cancer cells) after $48 \mathrm{~h}$ treatment with OGEO, OG-MeOH and the synthesised CS and TMC nanoparticles at various concentrations $\left(0-100 \mu \mathrm{g} \mathrm{mL}{ }^{-1}\right)$ are represented in Figure 13. An exclusion
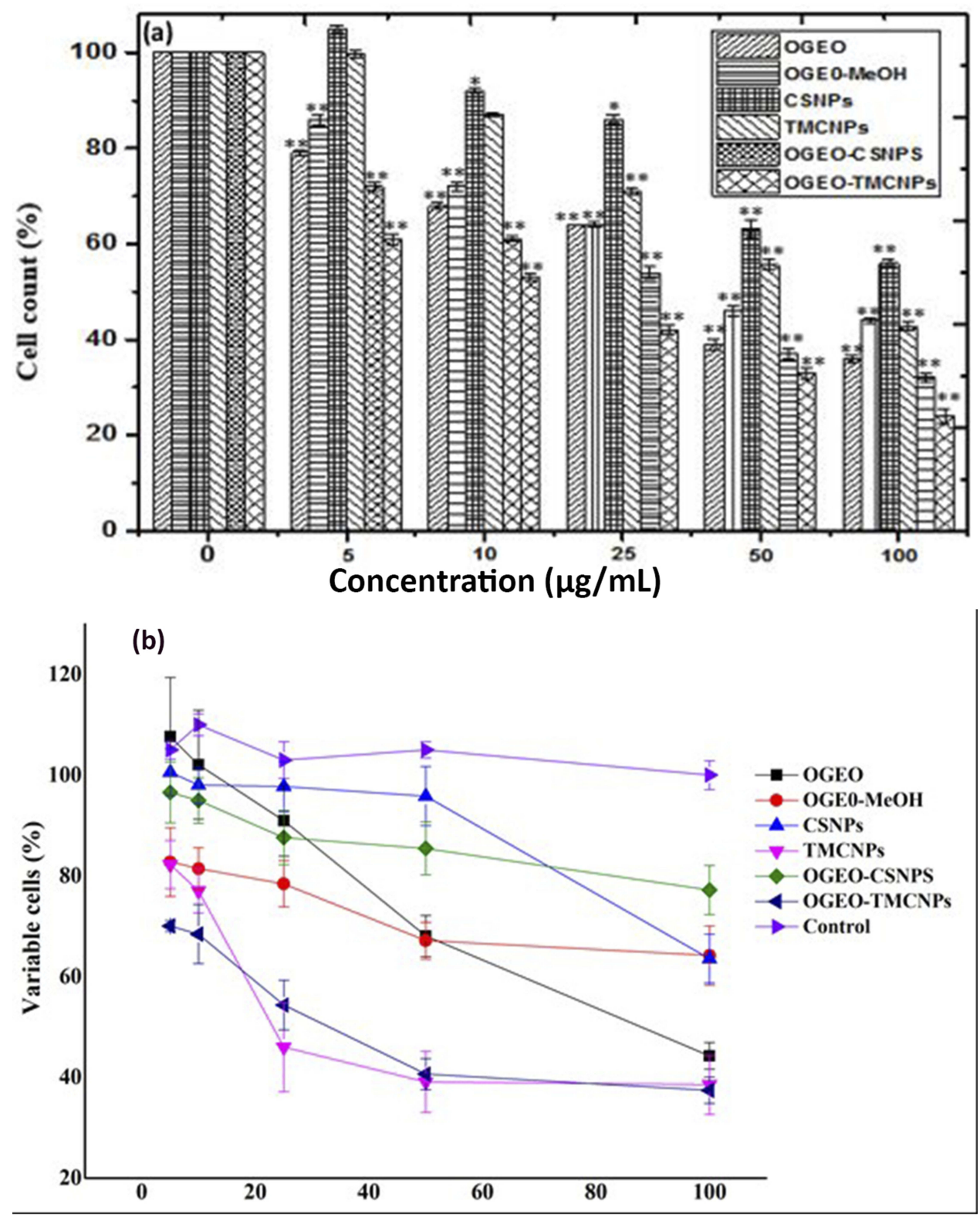

Concentration $(\mu \mathrm{g} / \mathrm{mL})$

Figure 13 Effect of treatment with free 0 . gratissimum EOs, methanolic extracts, free and OGEO-loaded chitosan and N, N, N-Trimethyl chitosan nanoparticles. (A) Proliferation of MDa-MB 23 I cells, (B) viability of MDa-MB 23 I cells. (Columns and bars represent means \pm standard deviation) $* P \leq 0.05$ and $* * P \leq 0.01$ represents the statistical difference between treatment with controls (DMEM) and $O$. gratissimum methanolic extract, EOs and nanoparticles.

Abbreviations: OGEO, Ocimum gratissimum essential oils; OG-MeOH, Ocimum gratissimum methanolic extract; CSNPs, chitosan nanoparticles; TMCNPs, trimethyl chitosan nanoparticles. 
A
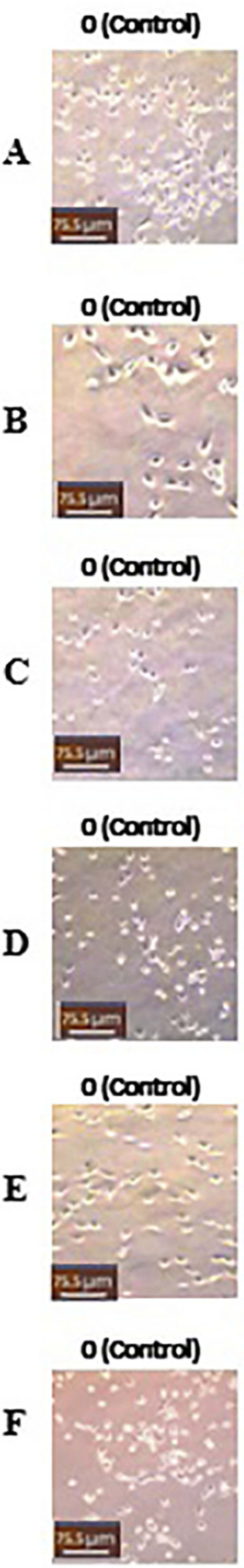
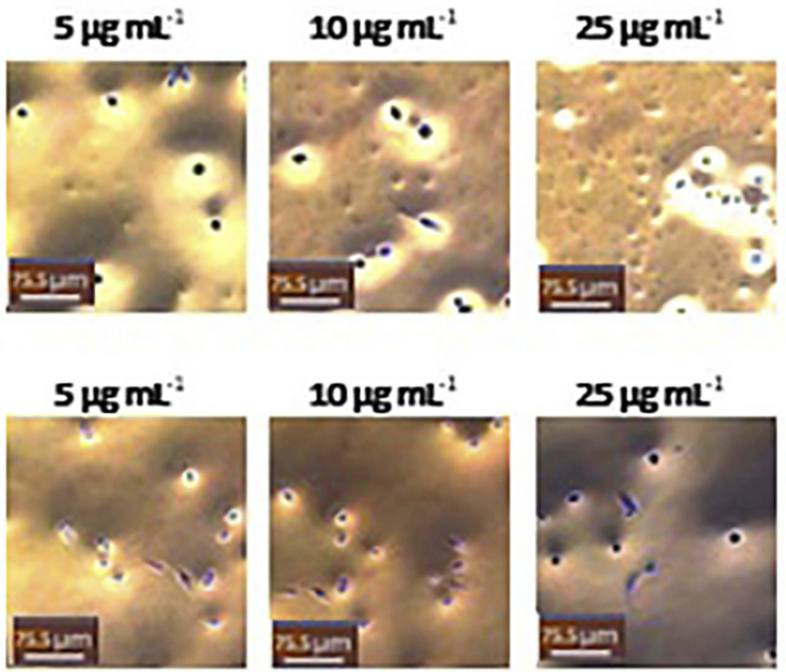

\section{$25 \mu \mathrm{mL}^{-1}$}
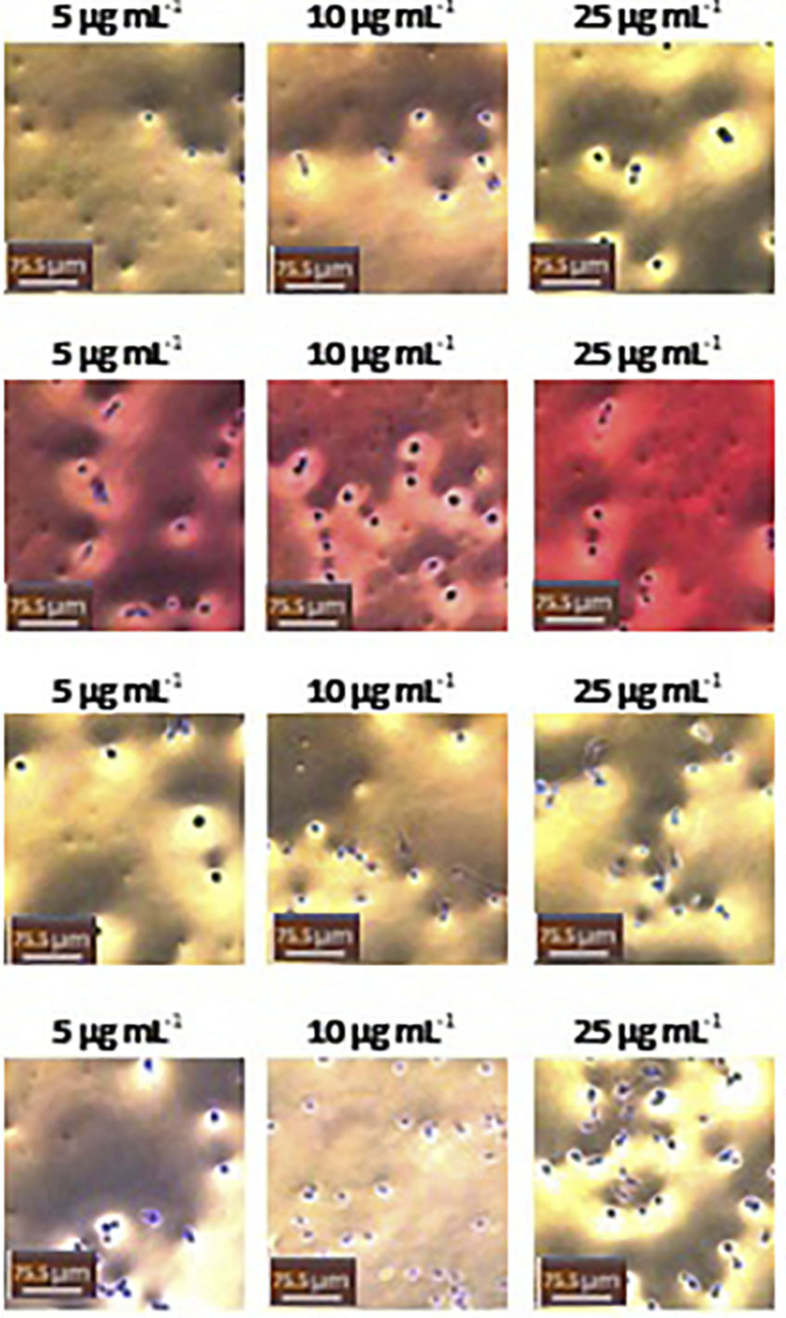
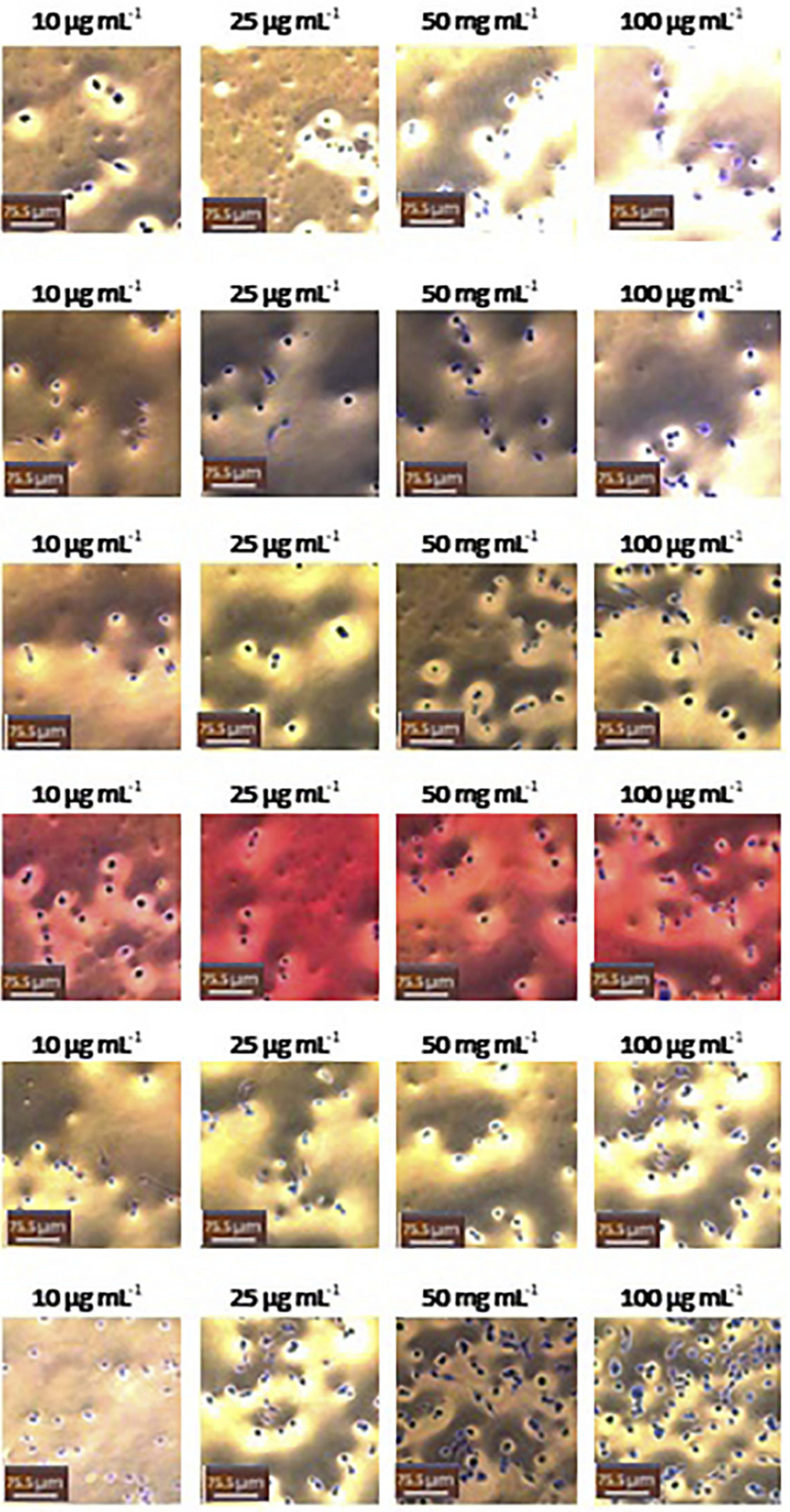
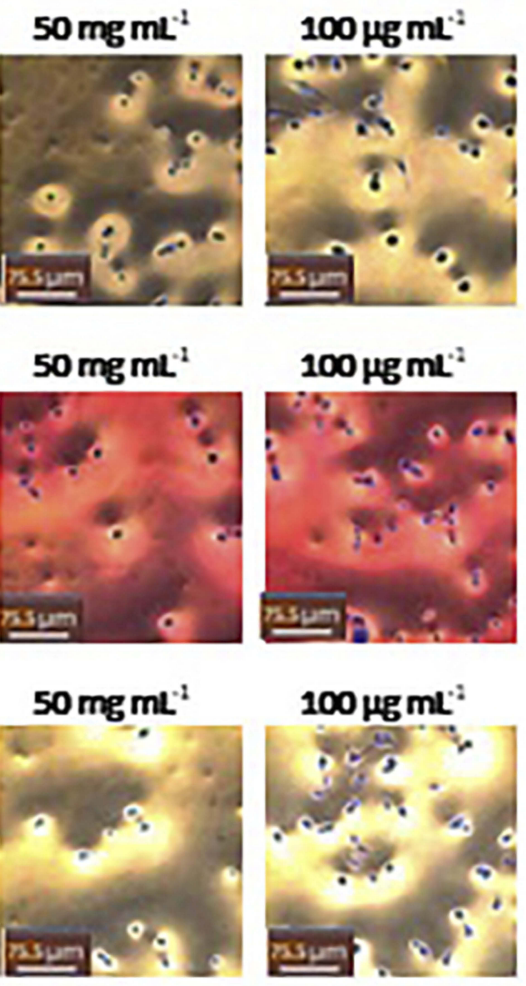

$100 \mu \mathrm{gl} \mathrm{ml}^{2}$

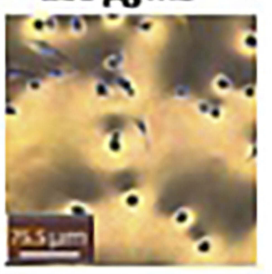

\section{$100 \mu \mathrm{gl}^{2}$}

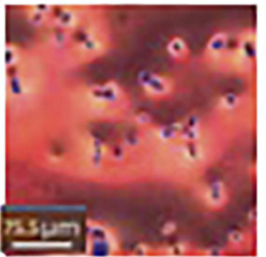

\section{$50 \mathrm{mg} \mathrm{mL}^{-1}$}

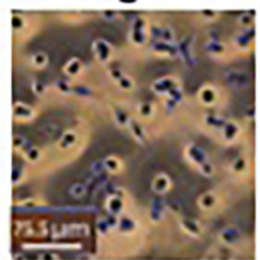

$100 \mathrm{Hgl}^{2}$

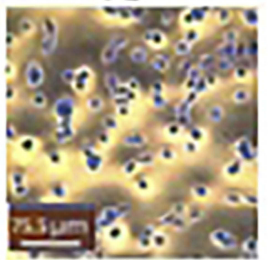

Figure 14 Light microscope images (20x) of MDA-MB-23I cells treated with different concentrations of samples: (A) CSNPs, (B) TMCNPs, (C) OG-MeOH, (D) OGEOs, (E) OGEO-CSNPs and (F) OGEO-TMCNPs. The non-treated cells (control) contained only DMEM (left panel). Scale bars $=75.5 \mu \mathrm{m}$.

Abbreviations: OGEO, Ocimum gratissimum essential oils; OG-MeOH, Ocimum gratissimum methanolic extract; CSNPs, chitosan nanoparticles; TMCNPs, trimethyl chitosan nanoparticles. 


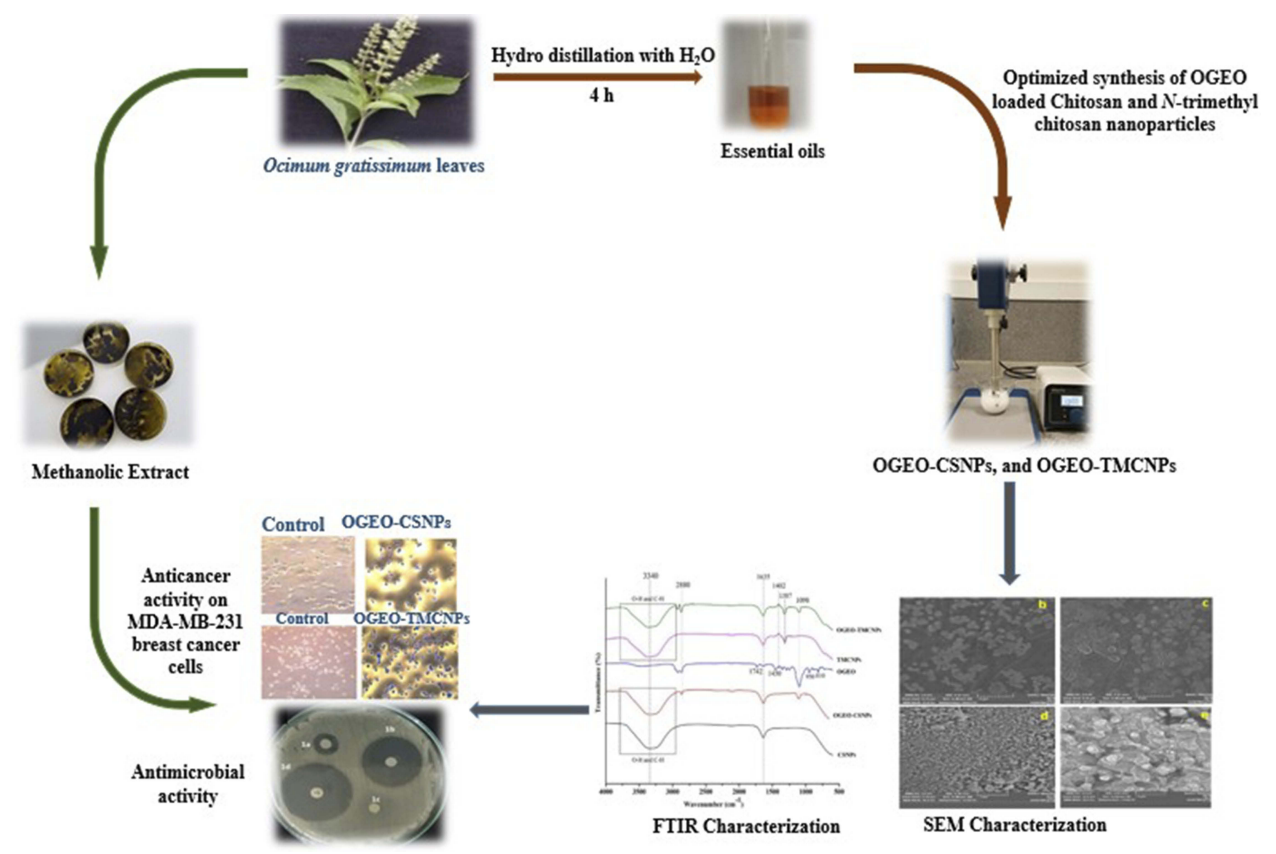

Figure I5 Summary of the optimised synthesis, characterisation and bioactivity application of OGEO-loaded chitosan and N, N, N-trimethyl chitosan nanoparticles.

assay with trypan blue dye revealed that the viability of the cells decreased with a corresponding increase in drug concentration. The results also indicated that OGEO-TMCNPs significantly inhibited the viability of the cancer cell line at much lower concentrations $(\mathrm{P}<0.05, \mathrm{n} \geq 3$, Figure 13A) compared to treatment with free OGEO, OGEO-MeOH and the remaining nanoparticles. Pulgazhendi et al emphasised that chitosan nanoparticles penetrate the cancerous cells membrane, leading to DNA damage and defects in the genes of the cells. ${ }^{9}$ Furthermore, Shanmuganathan et al reported that the apoptosis of tumour cells due to therapy using nanoparticles of chitosan and its derivative is the result of the nanoparticles interfering with cell growth and metabolism. ${ }^{8}$ The highest concentration (100 $\mu \mathrm{g} \mathrm{mL}^{-1}$ ) for OGEO, OGEO-MeOH, CSNPs, TMCNPs, OGEO-CSNPs and OGEO-TMCNPs decreased the viability of cancer cells to $44.25 \%, 64.19 \%, 63.56 \%, 38.53 \%, 77.19 \%$ and $37.44 \%$, respectively (Figure 13B). Typical phase-contrast light microscope images showing the retention of trypan blue dye by the drug-treated and non-treated (control) cancer cells are presented in Figure 14. Membrane blebs were also observed with cancer cells treated with OGEO-TMCNPs after $48 \mathrm{~h}$ of incubation. As suggested by Umar et al, cell membrane blebbing is an indication of cell apoptosis. ${ }^{56}$

The high antiproliferation activity of OGEO-TMCNPs on MDA-MB-231 breast cancer cells compared to the remaining nanoparticles and $\mathrm{OG}$ extracts were likely due to the generation of oxidative stress with the cell membrane. ${ }^{53}$ A summary of the entire process involved in the synthesis of OGEO-loaded nanoparticles and their in vitro biomedical applications is presented in Figure 15.

\section{Conclusion}

The bioactive components of OGEO are prone to environmental degradation due to their lipophilic nature. Moreover, the encapsulation of OGEO into CS and TMC nanoparticles requires optimisation conditions for the synthesis of nanoparticles with distinct physiochemical and bioactive properties, which were evidently carried out in this study. The synthesised OGEO-loaded CS and TMC nanoparticles revealed their potential food and medical applications due to their wide solubility at different physiological $\mathrm{pH}$ ranges and their bioactivity as antioxidants as well as antibacterial and anticancer agents.

\section{Acknowledgments}

The authors would like to extend their appreciation to the Hacettepe University HUNITEK Laboratory in Ankara, Turkey for their assistance in the characterisation experiments. The authors also appreciate the Biotechnology Research Centre (CIU) for its technical support and research funding.

\section{Disclosure}

The authors report no conflicts of interest in this work. 


\section{References}

1. Jessberger N, Kranzler M, Da Riol C, et al. Assessing the toxic potential of enteropathogenic Bacillus cereus. Food Microbiol. December 2019;84:103276. https://doi.org/10.1016/j.fm.2019.103276

2. Chang Y, Yoon H, Kang D, Chang P, Ryu S. Endolysin LysSA97 is synergistic with carvacrol in controlling Staphylococcus aureus in foods. Int J Food Microbiol. 2017;244:19-26.

3. Gasparetto A, Bella Cruz A, Wagner T, Bonomini T, Correa R, Malheiros A. Seasonal variation in the chemical composition, antimicrobial and mutagenic potential of essential oils from Piper cernuum. Ind Crops Prod. 2017;95:256-263.

4. Chase-Topping M, Rosser T, Allison L, et al. Pathogenic potential to humans of bovine escherichia coliO26, Scotland. Emerging Infect Dis. 2012;18(3):439-448.

5. Shetta A, Kegere J, Mamdouh W. Comparative study of encapsulated peppermint and green tea essential oils in chitosan nanoparticles: encapsulation, thermal stability, in-vitro release, antioxidant and antibacterial activities. Int J Biol Macromol. 2019;126:731-742.

6. Barcenas C. Annual report to the nation on the status of cancer, 1975-2011, featuring incidence of breast cancer subtypes by race/ ethnicity,poverty, and state. Breast J. 2016;27(1):36-38.

7. Siegel R, Miller K, Jemal A. Cancer statistics, 2018. CA Cancer J Clin. 2018;68(1):7-30.

8. Shanmuganathan R, Edison T, LewisOscar F, Kumar P, Shanmugam S, Pugazhendhi A. Chitosan nanopolymers: an overview of drug delivery against cancer. Int J Biol Macromol. 2019;130:727-736.

9. Pugazhendhi A, Edison T, Karuppusamy I, Kathirvel B. Inorganic nanoparticles: a potential cancer therapy for human welfare. Int $J$ Pharm. 2018;539(1-2):104-111.

10. Sotelo-Boyás M, Correa-Pacheco Z, Bautista-Baños S, Corona-Rangel M. Physicochemical characterization of chitosan nanoparticles and nanocapsules incorporated with lime essential oil and their antibacterial activity against food-borne pathogens. $L W T$. 2017;77:15-20.

11. Kavaz D, Idris M, Onyebuchi C. Physiochemical characterization, antioxidative, anticancer cells proliferation and food pathogens antibacterial activity of chitosan nanoparticles loaded with Cyperus articulatus rhizome essential oils. Int J Biol Macromol. 2019;123:837-845.

12. Chimnoi N, Reuk-ngam N, Chuysinuan P, et al. Characterization of essential oil from Ocimum gratissimum leaves: antibacterial and mode of action against selected gastroenteritis pathogens. Microb Pathog. 2018;118:290-300.

13. Karimirad R, Behnamian M, Dezhsetan S. Application of chitosan nanoparticles containing Cuminum cyminum oil as a delivery system for shelf life extension of Agaricus bisporus. Lwt. 2019;106:218-228.

14. Hosseini S, Zandi M, Rezaei M, Farahmandghavi F. Two-step method for encapsulation of oregano essential oil in chitosan nanoparticles: preparation, characterization and in vitro release study. Carbohydr Polym. 2013;95(1):50-56.

15. Kulkarni A, Vanjari Y, Sancheti K, et al. New nasal nanocomplex self-assembled from charged biomacromolecules: N,N,N-Trimethyl chitosan and dextran sulfate. Int J Biol Macromol. 2016;88:476-490.

16. Hasheminejad N, Khodaiyan F, Safari M. Improving the antifungal activity of clove essential oil encapsulated by chitosan nanoparticles. Food Chem. 2019;275:113-122.

17. Malik A, Gupta M, Gupta V, Gogoi H, Bhatnagar R. Novel application of trimethyl chitosan as an adjuvant in vaccine delivery. Int $J$ Nanomed. 2018;13:7959-7970.

18. Kavaz D, Odabaş S, Güven E, Demirbilek M, Denkbaş E. Bleomycin loaded magnetic Chitosan nanoparticles as multifunctional nanocarriers. J Bioact Compat Polym. 2010;25(3):305-318.

19. Divya K, Smitha V, Jisha M. Antifungal, antioxidant and cytotoxic activities of chitosan nanoparticles and its use as an edible coating on vegetables. Int J Biol Macromol. 2018;114:572-577.
20. Sathiyavimal S, Vasantharaj S, LewisOscar F, Pugazhendhi A, Subashkumar R. Biosynthesis and characterization of hydroxyapatite and its composite (hydroxyapatite-gelatin-chitosan-fibrin-bone ash) for bone tissue engineering applications. Int $J$ Biol Macromol. 2019;129:844-852.

21. Patrulea V, Applegate L, Ostafe V, Jordan O, Borchard G. Optimized synthesis of O-carboxymethyl-N,N,N-trimethyl chitosan. Carbohydr Polym. 2015;122:46-52.

22. Malik A, Gupta M, Mani R, Gogoi H, Bhatnagar R. Trimethyl chitosan nanoparticles encapsulated protective antigen protects the mice against anthrax. Front Immunol. 2018;9. doi:10.3389/fimmu. 2018.00562.

23. Pavithra P, Mehta A, Verma R. Induction of apoptosis by essential oil from P. missionis in skin epidermoid cancer cells. Phytomedicine. 2018;50:184-195.

24. Nahdi A, Hammami I, Ali R, Kallech-Ziri O, El May A, El May M. Effect of Hypericum humifusum aqueous and methanolic leaf extracts on biochemical and histological parameters in adult rats. Biomed Pharmacother. 2018;108:144-152.

25. Shahidi F, Zhong Y. Measurement of antioxidant activity. J Funct Foods. 2015;18:757-781.

26. Zhang J, Wang Y, Jiang Y, et al. Enhanced cytotoxic and apoptotic potential in hepatic carcinoma cells of chitosan nanoparticles loaded with ginsenoside compound K. Carbohydr Polym. 2018;198:537-545.

27. Li Y, Wu C, Wu T, et al. Preparation and characterization of citrus essential oils loaded in chitosan microcapsules by using different emulsifiers. J Food Eng. 2018;217:108-114.

28. Rakmai J, Cheirsilp B, Mejuto J, Torrado-Agrasar A, Simal-Gándara J. Physico-chemical characterization and evaluation of bio-efficacies of black pepper essential oil encapsulated in hydroxypropyl-betacyclodextrin. Food Hydrocoll. 2017;65:157-164.

29. Bajalan I, Rouzbahani R, Pirbalouti A, Maggi F. Antioxidant and antibacterial activities of the essential oils obtained from seven Iranian populations of Rosmarinus officinalis. Ind Crops Prod. 2017;107:305-311.

30. Moghaddam M, Farhadi N. Influence of environmental and genetic factors on resin yield, essential oil content and chemical composition of Ferula assa-foetida L. populations. J Appl Res Med Aromat Plants. 2015;2 (3):69-76.

31. Dutta S, Ray S. Comparative assessment of total phenolic content and in vitro antioxidant activities of bark and leaf methanolic extracts of Manilkara hexandra (Roxb.) Dubard. J King Saud Unive Sci. 2018. doi:10.1016/j.jksus.2018.09.015

32. Gillberg L, Varsanyi M, Sjöström M, Lördal M, Lindholm J, Hellström P. Nitric oxide pathway-related gene alterations in inflammatory bowel disease. Scand J Gastroenterol. 2012;47(11):1283-1298.

33. Santana A, Pereira G, Boaventura C, Uetenabaro A, Costa L, de Oliveira R. Rupture of glandular trichomes in Ocimum gratissimum leaves influences the content of essential oil during the drying method. Rev Bras De Farmacogn. 2014;24(5):524-530.

34. Olamilosoye K, Akomolafe R, Akinsomisoye O, Adefisayo M, Alabi $\mathrm{Q}$. The aqueous extract of Ocimum gratissimum leaves ameliorates acetic acid-induced colitis via improving antioxidant status and hematological parameters in male Wistar rats. Egypt J Basic Appl Sci. 2018;5(3):220-227.

35. Xu T, Xin M, Li M, Huang H, Zhou S. Synthesis, characteristic and antibacterial activity of N,N,N-trimethyl chitosan and its carboxymethyl derivatives. Carbohydr Polym. 2010;81(4):931-936.

36. Jiang C, Sun G, Zhou Z, et al. Optimization of the preparation conditions of thermo-sensitive chitosan hydrogel in heterogeneous reaction using response surface methodology. Int J Biol Macromol. 2019;121:293-300.

37. Asasutjarit R, Theerachayanan T, Kewsuwan P, Veeranondha S, Fuongfuchat A, Ritthidej G. Gamma sterilization of diclofenac sodium loaded- $\mathrm{N}$-trimethyl chitosan nanoparticles for ophthalmic use. Carbohydr Polym. 2017;157:603-612. 
38. Wu M, Long Z, Xiao H, Dong C. Preparation of N, N, N-Trimethyl chitosan via a novel approach using dimethyl carbonate. Carbohydr Polym. 2017;169:83-91.

39. Woranuch S, Yoksan R. Eugenol-loaded chitosan nanoparticles: I. Thermal stability improvement of eugenol through encapsulation. Carbohydr Polym. 2013;96(2):578-585.

40. Mithun U, Vishalakshi B, Karthika J. Preparation and characterization of polyelectrolyte complex of N,N,N-trimethyl chitosan/gellan gum: evaluation for controlled release of ketoprofen. Iran Polym J. 2016;25(4):339-348.

41. Lai P, Daear W, Löbenberg R, Prenner E. Overview of the preparation of organic polymeric nanoparticles for drug delivery based on gelatine, chitosan, poly(d,l-lactide-co-glycolic acid) and polyalkylcyanoacrylate. Colloids Surf B. 2014;118:154-163.

42. Pardeshi C, Belgamwar VN. N, N-trimethyl chitosan modified flaxseed oil based mucoadhesive neuronanoemulsions for direct nose to brain drug delivery. Int J Biol Macromol. 2018;120:2560-2571.

43. Zhang F, Fei J, Sun M, Ping Q. Heparin modification enhances the delivery and tumor targeting of paclitaxel-loaded N -octyl- N -trimethyl chitosan micelles. Int J Pharm. 2016;511(1):390-402.

44. Yoksan R, Jirawutthiwongchai J, Arpo K. Encapsulation of ascorbyl palmitate in chitosan nanoparticles by oil-in-water emulsion and ionic gelation processes. Colloids Surf B. 2010;76(1):292-297.

45. Hasani S, Ojagh S, Ghorbani M. Nanoencapsulation of lemon essential oil in Chitosan-Hicap system. Part 1: study on its physical and structural characteristics. Int J Biol Macromol. 2018;115:143-151.

46. Zou X, Zhao X, Ye L. Synthesis of cationic chitosan hydrogel with long chain alkyl and its controlled glucose-responsive drug delivery behavior. RSC Adv. 2015;5(116):96230-96241.

47. Choi J, Ramasamy T, Kim S, et al. PEGylated lipid bilayer-supported mesoporous silica nanoparticle composite for synergistic co-delivery of axitinib and celastrol in multi-targeted cancer therapy. Acta Biomater. 2016;39:94-105.
48. Keawchaoon L, Yoksan R. Preparation, characterization and in vitro release study of carvacrol-loaded chitosan nanoparticles. Colloids Surf B. 2011;84(1):163-171.

49. Anitha A, Deepagan V, Divya Rani V, Menon D, Nair S, Jayakumar R. Preparation, characterization, in vitro drug release and biological studies of curcumin loaded dextran sulphate-chitosan nanoparticles. Carbohydr Polym. 2011;84(3):1158-1164.

50. Kfoury M, Auezova L, Ruellan S, Greige-Gerges H, Fourmentin S. Complexation of estragole as pure compound and as main component of basil and tarragon essential oils with cyclodextrins. Carbohydr Polym. 2015;118:156-164.

51. Kamimura J, Santos E, Hill L, Gomes C. Antimicrobial and antioxidant activities of carvacrol microencapsulated in hydroxypropyl-betacyclodextrin. LWT Food Sci Technol. 2014;57(2):701-709.

52. Zhang J, Tan W, Wang G, et al. Synthesis, characterization, and the antioxidant activity of N, N, N -trimethyl chitosan salts. Int J Biol Macromol. 2018;118:9-14.

53. Mohammad F, Arfin T, Al-Lohedan H. Enhanced biological activity and biosorption performance of trimethyl chitosan-loaded cerium oxide particles. J Ind Eng Chem. 2017;45:33-43.

54. Bey-Ould Si Said Z, Haddadi-Guemghar H, Boulekbache-Makhlouf L, et al. Essential oils composition, antibacterial and antioxidant activities of hydrodistillated extract of Eucalyptus globulus fruits. Ind Crops Prod. 2016;89:167-175.

55. Khalili S, Mohsenifar A, Beyki M, et al. Encapsulation of thyme essential oils in chitosan-benzoic acid nanogel with enhanced antimicrobial activity against aspergillus flavus. LWT Food Sci Technol. 2015;60(1):502-508

56. Umar H, Kavaz D, Rizaner N. Biosynthesis of zinc oxide nanoparticles using Albizia lebbeck stem bark, and evaluation of its antimicrobial, antioxidant, and cytotoxic activities on human breast cancer cell lines. Int J Nanomed. 2019;14:87-100.
International Journal of Nanomedicine

\section{Publish your work in this journal}

The International Journal of Nanomedicine is an international, peerreviewed journal focusing on the application of nanotechnology in diagnostics, therapeutics, and drug delivery systems throughout the biomedical field. This journal is indexed on PubMed Central, MedLine, CAS, SciSearch ${ }^{\circledR}$, Current Contents ${ }^{\mathbb{R}} /$ Clinical Medicine,
Journal Citation Reports/Science Edition, EMBase, Scopus and the Elsevier Bibliographic databases. The manuscript management system is completely online and includes a very quick and fair peer-review system, which is all easy to use. Visit http://www.dovepress.com/ testimonials.php to read real quotes from published authors. 